\title{
Ranchers or pastoralists? Farm size, specialisation and production strategy amongst cattle farmers in south-eastern Kazakhstan
}

\author{
Sarah Robinson $^{1 *} \mathbb{D}$, Zhanyl Bozayeva ${ }^{2}$, Nozilakhon Mukhamedova ${ }^{1}$, Nodir Djanibekov $^{3}$ and Martin Petrick ${ }^{1,3}$
}

\begin{abstract}
Against the global trend towards sedentary, specialised and feed-intensive cattle farming, we explore current patterns of production in Kazakhstan's traditionally nomadic livestock sector. Experts see considerable potential for output expansion, and the government hopes to promote the sector as an alternative to revenues from hydrocarbons. Which production systems emerge will determine the use of the country's vast pastoral resources, patterns of economic contribution from livestock and future greenhouse gas emissions. We focus on the beef sector, using original survey data and interviews from south-eastern Kazakhstan to compare rural households and farms by production strategy, generated using cluster analysis from data on livestock holdings, fodder provision and grazing. We examine in particular the relationships between farm size and the characteristics identified. We find that, rather than being specialised and intensive, larger farms tend to be highly diversified in terms of stock species, are more mobile and provide fewer supplements per head than smaller farms. Winter pastures appear to be a key resource associated with larger operations. Many large farms provide fodder mainly as low-quality roughage, although a subset with better access to cropland provide higher quality rations and fatten cattle before sale. Medium-sized farms lack either winter pasture bases or cropland for growing supplements, but proximity to markets enables some to compensate through fodder purchases. Inability to access government support, available only to large farms, hampers their expansion. Farmers' professional background, distance from markets and environmental conditions are all associated with the production systems observed. In terms of policy, high transaction costs associated with leaseholds and lack of transferability between farmers impede access to land. Current pasture access mechanisms and institutions almost entirely exclude small farms and households. Changes in these systems, combined with infrastructure development, may bring economic, social and environmental benefits for the livestock sector and rural communities.
\end{abstract}

Keywords: Kazakhstan, Livestock, Pasture, Fodder, Intensification

\section{Introduction}

The global intensification of livestock production systems has been associated with significant gains in productivity and efficiency over the past 50 years (Davis et al. 2015, Herrero et al. 2015). Ruminant systems are less amenable to these forms of intensification, and most

\footnotetext{
*Correspondence: sarah.robinson09@gmail.com

${ }^{1}$ Justus Liebig University, Giessen, Germany

Full list of author information is available at the end of the article
}

animals continue to be raised on grass in earlier stages of development. But in developed countries, efficiency gains in feed conversion have been achieved through advances in animal health and genetics, pasture improvement and vertically coordinated intensive finishing stages (Crespi and Saitone 2019, Steinfeld et al. 2006). The grazing components of these systems are usually sedentary or ranch-based, with animals then physically
Springer Open (c) The Author(s). 2021 Open Access This article is licensed under a Creative Commons Attribution 4.0 International License, which permits use, sharing, adaptation, distribution and reproduction in any medium or format, as long as you give appropriate credit to the original author(s) and the source, provide a link to the Creative Commons licence, and indicate if changes were made. The images or other third party material in this article are included in the article's Creative Commons licence, unless indicated otherwise in a credit line to the material. If material is not included in the article's Creative Commons licence and your intended use is not permitted by statutory regulation or exceeds the permitted use, you will need to obtain permission directly from the copyright holder. To view a copy of this licence, visit http://creativecommons.org/licenses/by/4.0/. 
transported to grain-producing regions for finishing, for example in the USA.

In contrast, many arid regions of the developing world are characterised by mobile grazing systems, exploiting seasonal and spatial differences in vegetation to maximise nutrition from natural pastures over the year and minimising the purchase of expensive inputs. Many of these are now sedentarising and intensifying through replacement of seasonal pastures with cut fodder or feed and introduction of a fattening phase before slaughter. Drivers of such changes include new property rights systems, fragmentation of grazing systems due to land use change, and increasing market orientation (Behnke 2008, Dong et al. 2011, Reid et al. 2014).

These intensification and sedentarisation trends exhibit trade-offs, influencing attainment of Sustainable Development Goals (SDGs) related to food security, economic growth, life on land and climate (Kanter et al. 2016, Klapwijk et al. 2014, Salmon et al. 2018). The introduction of easily digestible fodder improves feed conversion efficiency, cuts greenhouse gas emissions and can reduce the land area required for livestock production (Davis et al. 2015, Herrero et al. 2015). But in arid regions, using scarce cropland for fodder reduces the area available to grow crops for direct human consumption, thus entailing high opportunity costs (van Zanten et al. 2016). Supplementary feeding can be costlier than exploitation of distant pastures (Fernández-Giménez and Ritten 2020), whilst sedentary or ranching types of husbandry may even reduce the output of meat per unit area, as heterogeneous fodder resources can no longer be exploited (Boone and Hobbs 2004). Even in industrialised countries, livestock owners in arid and risky environments are finding ways to maintain mobile forms of livestock production for these reasons (Behnke 2021, Huntsinger et al. 2010, McAllister et al. 2006).

One country increasingly faced by these trade-offs is Kazakhstan, which has some of the largest pasture resources globally. Kazakhstan has a long tradition of mobile pastoralism (Kerven et al. 2021), but has also experienced semi-industrialisation of livestock production in the Soviet period, during which state-supported mobile pastoralism was combined with considerable improvements in feeding, genetics and husbandry. Following the almost total collapse of the feeding, grazing and breeding aspects of these systems, Kazakhstan's hydrocarbon-based economic growth has fostered increasing domestic demand for meat and the government plans development of an export-oriented livestock sector (Ministry of Agriculture of the Republic of Kazakhstan 2018). This paper looks at the relative extents to which intensive, sedentary and specialised farming or mobile extensive production systems characterise beef production in south-eastern Kazakhstan, focusing in particular on relationships between farm size and the different feeding and husbandry strategies identified.

Covering 90\% of agriculturally usable land, rangelands in Kazakhstan have been exploited by both Soviet and pre-Soviet farming systems (Alimaev 2003, Fedorovich 1973, Zhambakin 1995). Much of this area remains unused today due to herd fragmentation following decollectivisation and breakdown in pasture infrastructure such as wells and roads (Broka et al. 2016, Hankerson et al. 2019). But recent studies on sheep production demonstrate the benefits of re-expansion into more remote areas in terms of liveweight gain and farm profitability (Issayeva and Bakhralinova 2020, Kerven et al. 2004, Kerven et al. 2016, Mirzabaev et al. 2016). In particular, the largest and most commercial producers are the most mobile, as these can afford to invest in winter base construction, water supply and transport (Kerven et al. 2004, Kerven et al. 2016, Milner-Gulland et al. 2006, Robinson et al. 2017). Seeking to make use of rangelands for livestock production, the country has invested in modernisation and intensification of the livestock sector, in particular large beef-producing enterprises (FAO Investment Centre 2010, Petrick et al. 2014). Beef is the most important meat product in Kazakhstan by monetary value (Oshakbayev and Bozayeva 2019) and cattle make up over 60\% (in livestock units) of the national herd.

However, little is known about current cattle production systems in Kazakhstan. Cattle are more dependent on fodder than sheep and have been associated with the sedentarisation of Kazakhs over the twentieth century (Kerven et al. 2021). On the one hand, production remains largely extensive, and in many parts of the country, these animals are moved to seasonal pastures along with other species (Hankerson et al. 2019; Kerven et al. 2021). On the other hand, concentration processes in beef and dairy production appear to be underway, partly driven by vertical integration and inflow of external capital (Petrick et al. 2014; Petrick and Götz 2019).

Against this background, we seek a deeper understanding of current farming systems in cattle husbandry. Following our observations above, we suggest two possible scenarios for future cattle production in Kazakhstan, which lie at opposite ends of many possible development trajectories:

- The intensive scenario involves specialisation, vertical coordination and possibly sedentary ranchtype structures, akin to the American model of beef production. Farmer-feedlots may emerge, as was common in the earlier stages of beef production in the USA (MacDonald and McBride 2009).

- The extensive scenario is closer to the traditional form of Kazakh livestock production, characterised 
by mixed herds, using more distant pastures and less fodder and feed as they grow. It is similar to the trajectory observed amongst sheep farms, as larger flocks allow owners to overcome the costs of access to quantitatively richer forage resources (Alimaev 2003, Kerven et al. 2004, Kerven et al. 2016, MilnerGulland et al. 2006, Mirzabaev et al. 2016, Robinson et al. 2017, Robinson and Milner-Gulland 2003b).

The two scenarios reflect our overarching question concerning whether livestock production in southeastern Kazakhstan now resembles sedentary or ranchtype operations making substantial use of fodder and feed, extensive pastoralism characterised by high levels of mobility and lower fodder provision, or something in between, using seasonal pastures combined with intensive feeding of selected stock. We also examine the extent of specialisation in particular livestock species and, within cattle production, into age and feeding stages. Livestock holding size was one factor used to generate feeding strategy clusters, but because size has such a fundamental effect on the economics of livestock production (Delgado et al. 2008, McDermott et al. 2010), we explore in detail the relationship of this factor with farm characteristics.

We focus on cattle, in the context of mixed livestock farms holding multiple species, at a site in Almaty province close to the Tienshan mountains, one of Kazakhstan's premier livestock-producing areas (Ferret 2018). This site represents areas long characterised by mobile systems and is thus an appropriate area to investigate their current status. In northern and western parts of the country, mobility already reduced considerably during the Soviet period and patterns are likely to be different, with some evidence of further sedentarisation in some places (Khanyari et al. 2021). We draw on original survey and interview data, collected in 2018 amongst both livestock-owning households and the more commercially oriented operations which have registered as 'farms'. We do not include large enterprises in our study as these hold relatively few stock nationally, are few in number and are much more dependent on external investors and support than smaller operations (see below for definitions of these categories). Data were collected across three districts at increasing distance from the largest regional market of Almaty city, including both large pasture resources at different elevations and irrigated and rainfed arable areas. We aim to characterise current production systems relative to our two opposing scenarios and quantify their empirical relevance. We investigate in particular relationships between farm size (both an outcome and determinant of production strategy) and farm characteristics and go on to explore the geographical and historical determinants of production strategy. Moreover, we investigate the constraints faced by livestock producers and the policies meant to support them, and how these may contribute to the development of the production systems observed.

After introducing the background of livestock production in Kazakhstan and our site and data, we split our sample of farms into feeding strategy groups using principle components and cluster analysis, using dimensions of livestock holding size and fodder provision (quality and quantity), provenance of fodder (purchased or self-produced) and pasture use and mobility. Different combinations of these traits represent different production strategies, which we then describe in terms of mean farm size, feeding intensity, mobility and access to land resources, examining additional indicators of intensification such as specialisation, genetic improvement, mechanisation, use of credit and investment, and market orientation. We examine the relationships between farm size and the above traits by comparing groups generated along holding size alone (cattle ownership quartiles) and through statistical relationships between holding size and the traits concerned. Lastly, we explore potential explanatory factors associated with membership of feeding strategy and farm size groups, including geographical location, farmer history and education, access to markets and land and property rights arrangements.

The types and prevalence of farm scale and production system identified have implications for rural livelihoods, greenhouse gas emissions and the efficiency and opportunity costs of livestock production and for the economic value of Kazakhstan's vast rangeland resources. We conclude by discussing the relevance of our findings for policy-making in these areas and identifying salient research gaps.

\section{Livestock production in Kazakhstan: trends and policies \\ Collapse in the 1990 s}

Kazakhstan was a major supplier of livestock products to the Soviet Union, and during this period, a combination of mobile pasture use and investments in supplementary feeding allowed livestock numbers to reach historical highs (Robinson and Milner-Gulland 2003a). During the transition to a market economy, the sector suffered almost total collapse (Pomfret 2013, Suleimenov and Oram 2000), with a loss of $61 \%$ of livestock inventories (FAOSTAT 2021). ${ }^{1}$ Both nutritional pillars were negatively affected: a reduction in pasture access was related to the loss of state support for livestock migration and breakdown in infrastructure in remote areas, whilst feed

${ }^{1}$ Based on standard Kazakh sheep units (sheep and goat $=1 \mathrm{LU}$, horse $=6 \mathrm{LU}$, cattle $=5 \mathrm{LU}$ and camels $=7 \mathrm{LU})$; small stock numbers dropped by $70 \%$ and cattle by $59 \%$. 


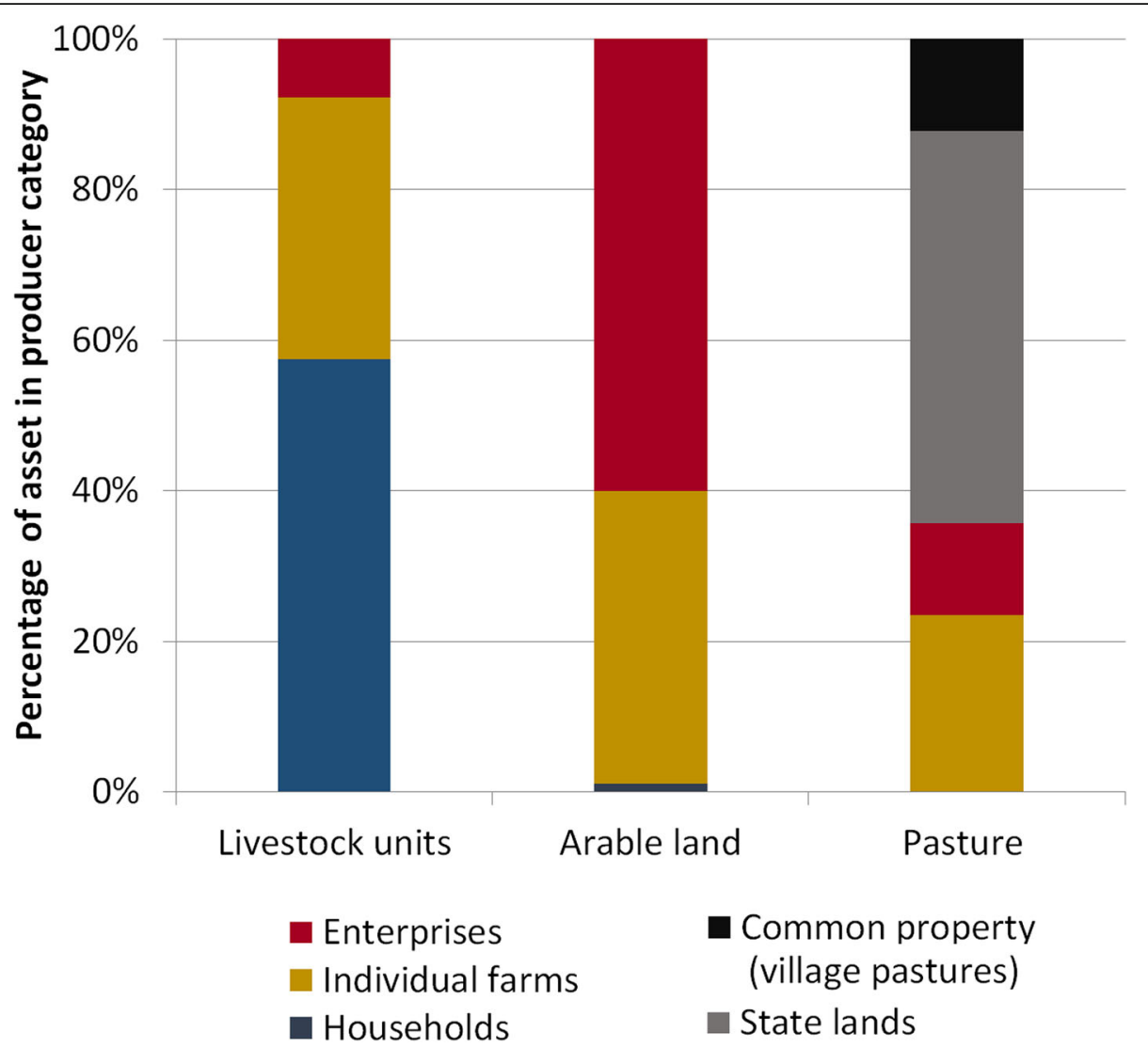

Fig. 1 Land and livestock distributions amongst different farm types in Kazakhstan. Source for data on livestock and arable lands: Kazakhstan Statistical Agency (downloadable tables for 2017); for pasture: Kazakhstan Statistical Agency (2014). State lands include unallocated reserve lands and pasture managed by the Forestry Department

availability collapsed as arable land was abandoned or converted to food crops (Robinson and Petrick 2021). But since the 2000s, the sector has been recovering. Increasing urban incomes have stimulated domestic demand for livestock products, and given its extensive rangelands, Kazakhstan is widely expected to become an important global exporter of meat and dairy products once again (Hankerson et al. 2019). Yet animal performance is poor, with low milk and beef yields per head of cattle compared to other emerging economies (Robinson 2020). Both meat and milk production are still below their pre-transition level and meat and dairy imports continue to dwarf exports despite recent progress following Kazakhstan's designation as a foot and mouth disease-free zone.

\section{The current producer landscape}

Because both supplementary feeding and pasture use are so much lower than in the past, there is room for both intensification and extensification in the sector, and both are indeed occurring. However, the opportunities and constraints associated with these strategies vary according to farm structure and size. Post-Soviet reforms resulted in three main types of livestock holding: (i) large enterprises, often privatised successor institutions of collective and state farms; (ii) individual farms, registered farming entities created from land distribution to former workers; and (iii) rural households-who did not receive land shares and cannot access long-term leaseholds, but usually hold a kitchen garden in private ownership. Households generally own few animals but collectively hold the bulk of national inventories-yet they have legal access only to pastures around villages, areas located within formally designated 'settlement lands' ${ }^{2}$ allocated to municipalities and set aside for common grazing (Fig. 1). Individual farms are now regulated by the Entrepreneurial Code and are considered commercial entities, in contrast to more subsistence-oriented households. Thus, throughout this paper, we refer to 'farms' and households. But as we will see, there is some overlap between the two categories in terms of livestock production. Farms also hold kitchen gardens but there is no distinction for most farmers between the 'household' part of their operation and the legally registered entity so we do not attempt to separate

\footnotetext{
${ }^{2}$ Chapter 11, article 107 of the Land Code.
} 
the two. Large enterprises and individual farms may lease arable or pastureland for up to 49 years from the state, but for those who did not receive land shares in the 1990s, acquisition entails considerable transaction costs as most of this land is now allocated by auction. Individual farms now hold the largest proportion of formally allocated pastures, whilst large enterprises hold a disproportionate share of arable land, but few stock (Fig. 1). State reserve lands are as yet unallocated and for the moment are open access, but these are often located far from settlements or unserved by infrastructure. In our study area, large areas of pasture are under the jurisdiction of the Forestry Department, available for short-term lease.

\section{Factors affecting livestock production: environment and policy}

Since independence, successive state programmes have promoted the intensification of beef production systems, including considerable subsidies for large vertically integrated enterprises (FAO Investment Centre 2010, Petrick et al. 2014, Petrick et al. 2018). The latest beef production policy aims to establish an export-oriented sector through promotion of individual farms, producing calves from cows fed on pasture, followed by sale to feedlots for finishing (Ministry of Agriculture of the Republic of Kazakhstan 2018). Subsidies for individual farmers include payments covering up to $50 \%$ of the cost of pedigree livestock, support for feedlot establishment, output subsidies for raw produce sold to processors and a number of credit lines with subsidised interest rates (Government of Kazakhstan 2017). It is also hoped that intensification through improved feed quality can support attainment of Kazakhstan's climate change commitments (World Bank 2019). Agriculture accounts for 9\% of national emissions, over $50 \%$ of which are accounted for by enteric fermentation alone (UNFCCC 2019).

Feed cost and availability are major impediments to this vision (Broka et al. 2016, Petrick et al. 2014). Only $8 \%$ of the country is covered by arable land, most of which is rainfed and found in the north of the country; elsewhere, crops must be irrigated (FAO 2013). Fodder crops (excluding grain) now cover $15 \%$ of all arable land. But this area still represents only around 30\% of the 1992 figure (Djanibekov and Petrick 2020). Fodder is now designated as a 'priority' crop, eligible for area payments as part of Kazakhstan's efforts to diversify away from wheat (OECD 2020), but many farms, and households in particular, have little access to cropland (Fig. 1).

\section{Study site}

The study site includes the eastern end of Enbekshikazakh district and (former) Raiymbek district, close to the Chinese and Kyrgyz borders in Almaty province (Fig. 2). At the time of the survey, Raiymbek district was in the process of being split into two new districts: Kegen (based on the district centre of Kegen) and 'new' Raiymbek (based on the district centre of Narynkol in the east). The border between these two new districts runs north-south just to the east of Kegen.

The area hosts a vertical transhumance regime between alpine summer pastures (jailau) and remote winter pastures on south-facing or other snow-free areas, with settlements in between (Ferret (2018), Fig. 3). Thus, animals, if mobile, can theoretically be kept on pasture virtually all year around. At least some of the migratory routes used during the Soviet period, and today, are based on traditional patterns-reflecting those used by pre-Soviet pastoralists (ibid.) The western end of the site is around $100 \mathrm{~km}$ from the large regional market of Almaty, whilst the eastern end is over $300 \mathrm{~km}$ distant. The site also includes a range of environmental conditions for supplementary fodder production, with availability of irrigated arable lands in Enbekshikazakh and 'new' Raiymbek and harsher conditions in Kegen, which is at higher altitude. Basic statistical data on livestock and land were collected from district centres following which a quantitative survey and semi-structured interviews were conducted with households and farms.

\section{Methods}

\section{Survey and interviews}

Fifty households and two hundred farms were selected through a two-stage sampling process, with first sub-district, then farmers and households sampled at random using existing lists for farmers and random visits for households. Because households and farms are taken from two different sampling frames, all data for households are presented separately from those of farms. The survey, conducted in 2018, covered topics on the history and structure of the household or farm, livestock ownership, cattle herd structure, access to cropland and pastures, supplementary feeding, marketing, genetics and breeding, subsidies and loans, livestock health and investment and farm development-including constraints to growth. Owners were targeted where possible and in the final sample these concerned $70 \%$ of respondents, whilst $30 \%$ were other household members or managers. A subset of the survey sample was also interviewed in depth in 2019, covering twenty interviewees (all of whom were owners) with a range of intensification and commercialisation characteristics, located at varying distances from Almaty (Fig. 2). Respondents were questioned on similar topics to those covered in the survey, but the more open interview format was used to clarify details and discuss aspects of farm decision-making. Other types of respondents 


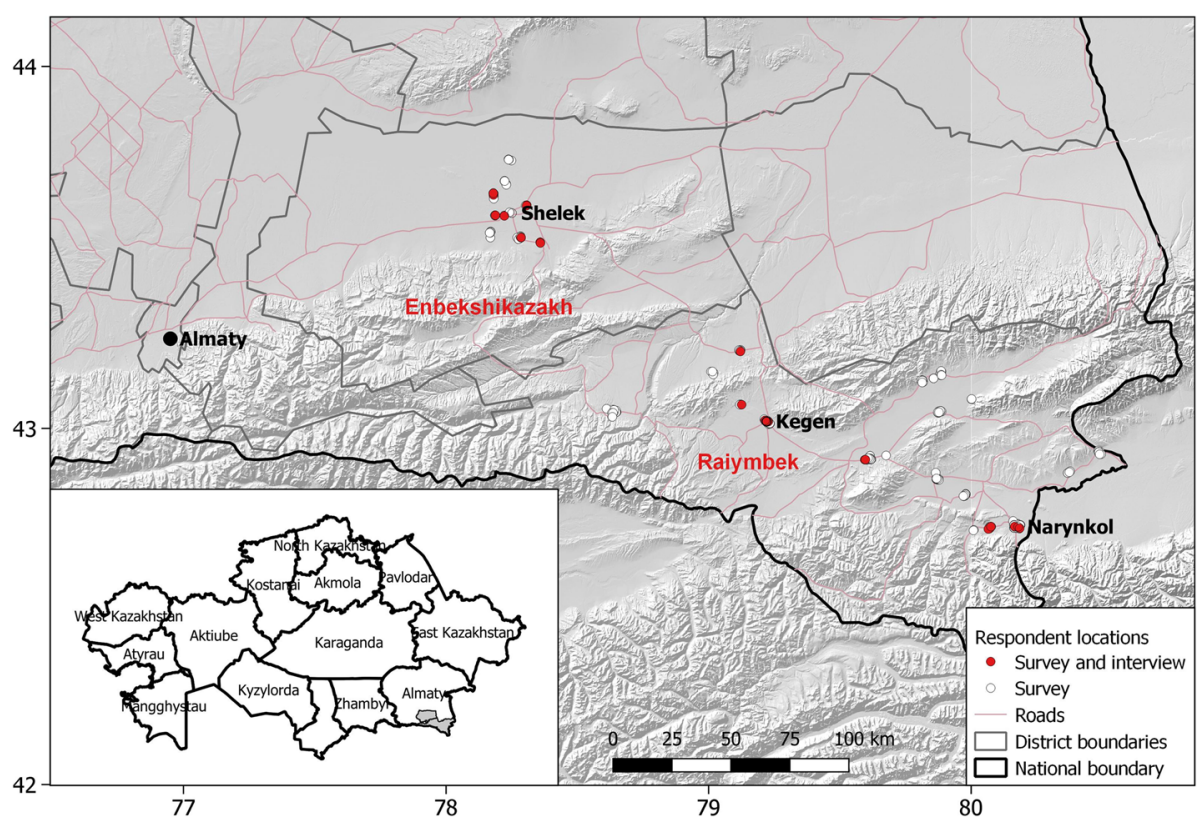

Fig. 2 Map of the study site. Note to figure: Raiymbek district is now split into two districts-Kegen in the west and 'new' Raiymbek, based on the district centre of Naynkol, in the east. Projection and coordinate units are latitude and longitude

were also interviewed, including participants in beef value chains, such as livestock buyers and abattoir owners, as well as district officials, pasture experts and NGO staff involved in the implementation of the 2017 Law on Pastures.

\section{Data analysis}

\section{Classification of farmers}

Households were analysed as a single group whilst the 200 individual farms were classified in two different ways. Firstly, farms were split into quartiles by cattle ownership, reflecting scale alone as a criterion for grouping. A second grouping, which we label 'feeding strategy', was produced through cluster analysis using metrics combining scale, access to crop and pastureland, mobility and fodder provision (Table 1). Cluster analysis has been used by a number of authors to characterise livestock producers (Mubiru et al. 2007, Serneels et al. 2009, Solano et al. 2001). Whilst many of these use binary variables to classify farms, we use continuous variables as, whilst most farms may provide some concentrate or use

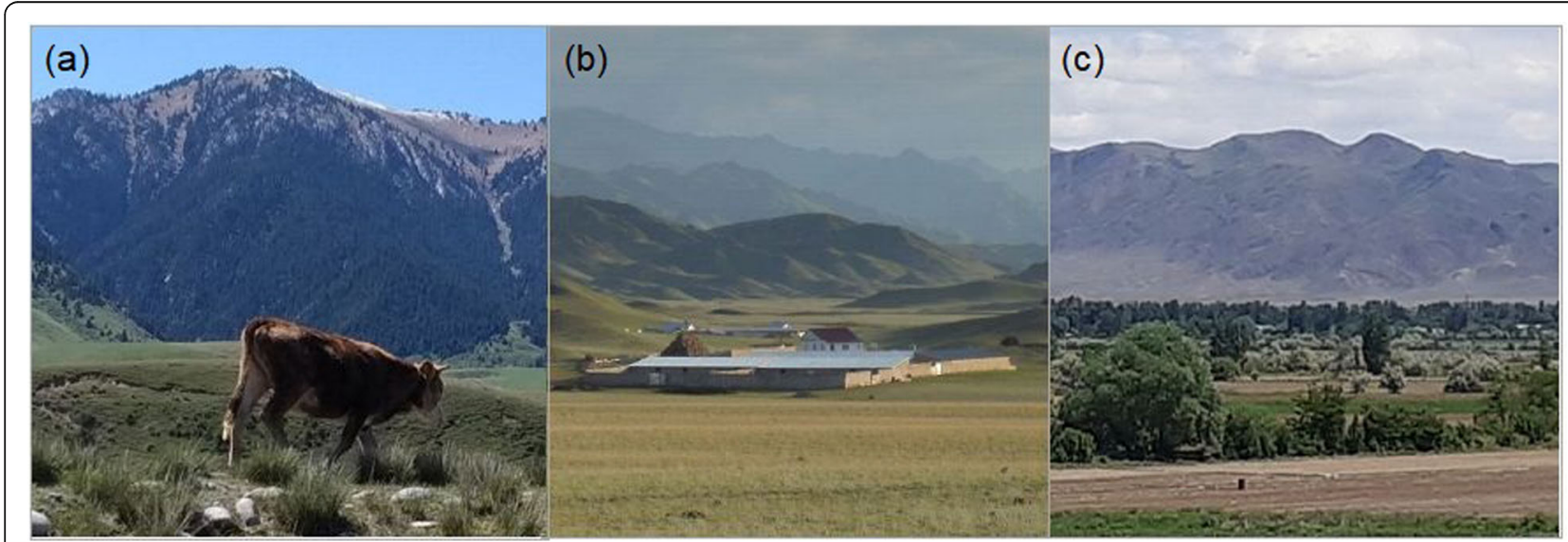

Fig. 3 Photos of the study site. a Summer area on the forest land. b Foothill pasture with winter base. c Irrigated zone with mountain pasture. Sources: All photos are taken by Sarah Robinson and Zhanyl Bozayeva 
Table 1 Metrics of scale and input intensification used to create clusters based on feeding strategy

\begin{tabular}{|c|c|}
\hline Metrics & Explanation \\
\hline \multicolumn{2}{|l|}{ Scale } \\
\hline Cattle (head) & Number of cattle owned \\
\hline Livestock unit & $\begin{array}{l}\text { Total livestock ownership } \\
\text { (all species)* }\end{array}$ \\
\hline \multicolumn{2}{|l|}{ Supplementary feed/fodder } \\
\hline Concentrate purchased (kg/head/year) & $\begin{array}{l}\text { Including grains and root } \\
\text { crops }\end{array}$ \\
\hline Concentrate grown (kg/head/year) & $\begin{array}{l}\text { Including grains and root } \\
\text { crops }\end{array}$ \\
\hline Roughage purchased (kg/head/year) & $\begin{array}{l}\text { Including natural hay**, } \\
\text { silage, cultivated hays } \\
\text { (sainfoin, lucerne) and crop } \\
\text { residues }\end{array}$ \\
\hline Roughage produced (kg/head/year) & $\begin{array}{l}\text { Including natural hay, silage, } \\
\text { cultivated hays (sainfoin, } \\
\text { lucerne) and crop residues }\end{array}$ \\
\hline Area of arable land used & $\begin{array}{l}\text { Arable land was defined as } \\
\text { land for growing crops }\end{array}$ \\
\hline \multicolumn{2}{|l|}{ Pasture use and livestock mobility } \\
\hline Pasture used (ha) & $\begin{array}{l}\text { The question asked about } \\
\text { formal access to pasture in } \\
\text { terms of contracts. So does } \\
\text { not include the use of village } \\
\text { pasture. }\end{array}$ \\
\hline $\begin{array}{l}\text { Time spent on off-village pasture } \\
\text { (months) }\end{array}$ & $\begin{array}{l}\text { Number of months spent on } \\
\text { pastures other than those } \\
\text { common pastures around the } \\
\text { village for which residents } \\
\text { have common grazing rights. }\end{array}$ \\
\hline
\end{tabular}

- Based on standard Kazakh sheep units (sheep and goat $=1 \mathrm{LU}$, horse $=6 \mathrm{LU}$ and cattle $=5 \mathrm{LU}$ )

**Natural hay is a mix of natural grass species occurring on uncultivated but ungrazed land set aside for this purpose. Cultivated hays are planted on arable land parcels and are generally perennial species such as lucerne

some pasture, it is often the relative quantities which reveal differences. Our variables of interest are not normally distributed (most follow a log normal distribution and contain large numbers of zeros). Moreover, many are strongly inter-related. To resolve these issues, the variables were logged (after addition of one to all values to remove zeros), standardised (using $z$-scores) and converted to a reduced number of dimensions using principal component analysis (PCA) (García-Martínez et al. 2009, Nieto et al. 2018). The PCA scores were then subjected to cluster analysis. Hierarchical clustering was ineffective as the elements of production systems have no obvious underlying hierarchy. Thus, $K$-means cluster analysis was used (Everitt et al. 2011), selecting a $K$ value of 6 following Makles (2012). The procedures were carried out using Stata routines 'pca' and 'cluster' (with option $\mathrm{k}$ (default means) and random number seed). The clusters as they relate to pairs of PCA scores are shown in Supplementary Materials 2.
Comparison of differences between feeding strategy clusters and between farm size quartiles

These groups, generated by holding size and feeding strategy cluster as described above, were then compared across a number of metrics representing livestock ownership, land access, fodder provision, pasture use, genetic improvement, mechanisation, access to credit, investment and commercialisation-including the original metrics used to create the farm size quartiles and clusters. Differences in feeding intensity were measured using annual fodder rations per head of various types. These were collected as weights in the survey, and each type of supplementary fodder was expressed in kilogrammes provided per head of cattle per year. But such raw weights do not reflect the quality of rations, so indicative conversions to protein were also made, using standard conversion factors available in AFRC Technical Committee on Responses to Nutrients (1993).

Secondly, a set of farm and farmer characteristics were compared across the farm size and feeding strategy groups in order to explore factors associated with the production system identified. These included membership of former collective farms (found to be related to access to land and other assets in Kazakhstan (Kerven et al. 2016)) and farmer education (positively related to metrics of feeding intensity around the world (Baltenweck et al. 2003)). Geographical location, distance from Almaty and size of home settlement are related to the physical conditions for livestock production and to distance from input and output markets. As access to pastureland and cropland are essential elements determining feeding strategy, the property rights arrangements on these lands were also examined in detail.

In the results, we present the means of the above-listed metrics for each feeding strategy cluster. Means for cattle ownership quartile are given in Supplementary Materials and referred to in the main text where scale is strongly associated with the farm characteristics concerned. All statistical relationships between holding size and farm characteristics are presented in the main body of the paper. These were found by regressing the predictor variable log of cattle ownership against the farm characteristic metrics listed above. Where these were skewed integer values with many zeros, negative binomial regressions were employed (Green 2021, St-Pierre et al. 2018). For non-integer continuous outcomes, OLS regression was used, with log transformation and addition of a constant of 1 to replace zeros where appropriate (ibid.). In the case of binary responses, we used logistic regression.

Statistical analysis of differences between feeding strategy clusters was also conducted. For continuous response variables, OLS regression (ANOVA) or negative binomial regressions were employed, using the six-level categorical predictor of the cluster. Here, we report the $F$ statistic or likelihood ratio chi-squared statistic that all coefficients in the model are simultaneously equal to 
zero, plus post-estimation pairwise comparisons using Bonferroni correction. For binary outcomes, we used Pearson's chi-squared test, followed by post hoc pairwise comparisons using adjusted Pearson's residuals with Bonferroni correction (Sharpe 2015).

\section{Results}

\section{PCA and cluster analysis}

Five components with an eigenvalue above one were obtained, explaining more than $85 \%$ of the total variance in input variables (Supplementary materials 2, Table A2.1, A2.2). These components could be identified as axes broadly representing (i) scale (livestock and pasture area), (ii) purchase of concentrate, (iii) self-production of roughage, (iv) use of remote pasture and (v) access to cropland and self-production of concentrate. Used as input to cluster analysis, the PCA scores for these five dimensions reveal structure in the data which is not visible using the raw variables (Supplementary materials 2, Figures A2.1 \& A2.2).

Table 2 summarises the broad characteristics of the six production strategies identified, which will be described further in the following sections. The clusters are numbered (i) in order of size and (ii) use of supplements (less to more; purchased to self-produced).

\section{Fodder provision and pasture use}

Table 3 summarises key farm characteristics for households and farm feeding strategy clusters and presents the regression coefficients between cattle holding size and each variable. Means for cattle ownership quartiles are shown in Table A3.1, Supplementary Materials. Binary equivalents of the continuous metrics listed (e.g. proportion of households and farm providing each fodder component; proportion holding each type of land) are given in Supplementary Materials, Table A3.2.
Amongst feeding strategy clusters, herd sizes cover a wide range but are still significantly different from one cluster to another, as scale is one aspect of the strategies identified. In terms of livestock holdings, the small sedentary category bears a strong resemblance to households, as does the smallest cattle ownership quartile (Q1, Table A3.1). Here, the difference in size between Q4 and Q3 is much larger than those between other quartiles, reflecting the $\log$ normal distribution of the datasetcharacterised by a few large operations and many smallholders. Differences in proportions of cattle between feeding strategy clusters, although significant, are small and only six farms hold exclusively cattle. However, it is notable that the large mobile fodder purchasers hold the lowest proportion of cattle. There is a strong relationship between cattle holding size and that of other stock species, and none at all between farm size and proportion of cattle in total livestock ownership, indicating a lack of general relationships between specialisation and size. Interviews suggested that holding multiple types of livestock spreads both risk and income streams over the year, so that seasonal costs for one species may be covered by sales from another. Households are much more likely to hold only cattle, a situation which concerns around $20 \%$ of the sample.

Around $86 \%$ of the individual farm sample use cropland and 71\% hayland (Table A3.2, Supplementary Materials). The high frequency of cropland access, which is similar in households, is associated with ownership of kitchen gardens (which are included in this category). But leasehold access over additional land is less prevalent (Table A3.2) and explains the difference in mean area between households and farms. Notably, less than $20 \%$ of the two fodder-purchasing clusters have access to leased cropland outside kitchen gardens, although the

Table 2 Basic characteristics of the six production clusters identified

\begin{tabular}{|c|c|c|c|c|}
\hline No. & $N($ of 200$)$ & $\%$ & Cluster short title & Description \\
\hline 1 & 40 & $20 \%$ & Small sedentary & $\begin{array}{l}\text { Small sedentary farms using mostly village pasture and having the highest } \\
\text { reliance on supplements in winter, including purchased concentrate. }\end{array}$ \\
\hline 2 & 56 & $28 \%$ & Medium mobile & $\begin{array}{l}\text { Medium farms with high mobility and access to pastures. Provide less } \\
\text { fodder per head than other medium operations ( } 3 \text { and } 4) \text {, mostly in } \\
\text { the form of self-produced roughage. Many use off-village pasture all year. }\end{array}$ \\
\hline 3 & 25 & $13 \%$ & Medium fodder purchaser & $\begin{array}{l}\text { Medium farms with almost no access to arable land, providing } \\
\text { large amounts of purchased supplements. Cover a wide range of } \\
\text { pasture use and mobility types, but the majority use off-village } \\
\text { summer pasture only. }\end{array}$ \\
\hline 4 & 32 & $16 \%$ & Medium fodder producer & $\begin{array}{l}\text { Medium farms with the highest mean cropland areas and volume } \\
\text { of concentrate provided per animal. This group has a range of pasture use } \\
\text { and mobility, but the majority use off-village pasture in summer pasture only. }\end{array}$ \\
\hline 5 & 27 & $14 \%$ & Large mobile fodder purchaser & $\begin{array}{l}\text { Large mobile extensive operation using both off-village winter } \\
\text { and summer pastures and providing mostly poor-quality } \\
\text { roughage (natural hay) in winter, much of which is purchased. }\end{array}$ \\
\hline 6 & 20 & $10 \%$ & Large mobile fodder producer & $\begin{array}{l}\text { Large mobile operation using both remote winter and } \\
\text { summer pastures, with access to cropland and provision } \\
\text { of high-quality self-produced fodder in relatively small quantities. }\end{array}$ \\
\hline
\end{tabular}


Table 3 Farm characteristics by feeding strategy (means include zeros unless specified in notes)

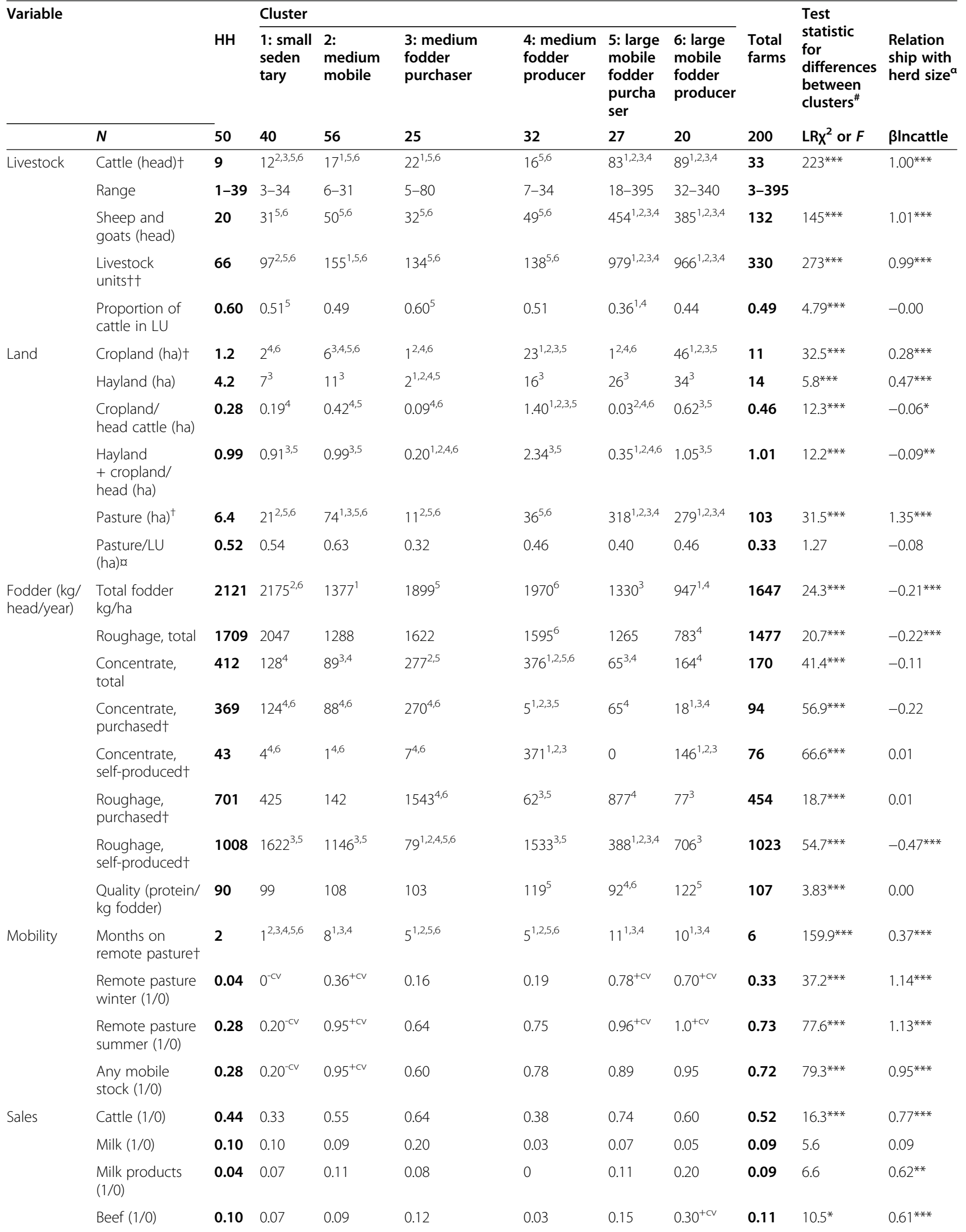


Table 3 Farm characteristics by feeding strategy (means include zeros unless specified in notes) (Continued)

\begin{tabular}{|c|c|c|c|c|c|c|c|c|c|c|c|}
\hline \multirow{2}{*}{\multicolumn{2}{|c|}{ Variable }} & \multirow[b]{2}{*}{$\mathrm{HH}$} & \multicolumn{6}{|l|}{ Cluster } & \multirow[b]{2}{*}{$\begin{array}{l}\text { Total } \\
\text { farms }\end{array}$} & \multirow{2}{*}{$\begin{array}{l}\text { Test } \\
\text { statistic } \\
\text { for } \\
\text { differences } \\
\text { between } \\
\text { clusters }^{\#}\end{array}$} & \multirow[b]{2}{*}{$\begin{array}{l}\text { Relation } \\
\text { ship with } \\
\text { herd size }^{a}\end{array}$} \\
\hline & & & $\begin{array}{l}\text { 1: small } \\
\text { seden } \\
\text { tary }\end{array}$ & $\begin{array}{l}\text { 2: } \\
\text { medium } \\
\text { mobile }\end{array}$ & $\begin{array}{l}\text { 3: medium } \\
\text { fodder } \\
\text { purchaser }\end{array}$ & $\begin{array}{l}\text { 4: medium } \\
\text { fodder } \\
\text { producer }\end{array}$ & $\begin{array}{l}\text { 5: large } \\
\text { mobile } \\
\text { fodder } \\
\text { purcha } \\
\text { ser }\end{array}$ & $\begin{array}{l}\text { 6: large } \\
\text { mobile } \\
\text { fodder } \\
\text { producer }\end{array}$ & & & \\
\hline & $N$ & 50 & 40 & 56 & 25 & 32 & 27 & 20 & 200 & $\mathrm{LRX}^{2}$ or $F$ & Blncattle \\
\hline & $\begin{array}{l}\text { Carcass weight } \\
\text { bullocks (kg)ad }\end{array}$ & 139 & 130 & 150 & 180 & 183 & 157 & 207 & 166 & $2.5^{* *}$ & $28.8^{* * *}$ \\
\hline
\end{tabular}

\footnotetext{
\#Continuous variables: Test statistic likelihood ratio $\left(x^{2}\right)$ values for negative binomial regressions with cluster as the categorial predictor against the variables for livestock numbers, months on pasture, and fodder. For carcass weight, cattle as the proportion of LU, protein content and continuous land variables (log transformed), OLS regression (ANOVA) was used and the $F$ ratio is reported. ${ }^{* * *} p<0.01,{ }^{* *} p<0.05,{ }^{*} p<0.1$

Superscripts $1,2,3,4,5$ and 6 indicate clusters with which a significant difference exists at ${ }^{* *} p<0.05$ or lower using pairwise comparisons with Bonferroni correction

"Binary variables: Pearson's chi-squared test on variable listed against the cluster, ${ }^{* * *} p<0.01,{ }^{* *} p<0.05,{ }^{*} p<0.1$

Superscript $+/-c v$ for binary variables indicates cells with Pearson's residuals greater than the critical value with Bonferroni correction (+ or -2.86$)$, indicating contribution to $x^{2}$

${ }^{a}$ Slope coefficients of regressions of log of cattle ownership against outcome variables. For carcass weight, cattle as the proportion of LU and land variables (the last of which were log transformed), OLS regression was employed; for counts of livestock numbers, months on pasture and kilogramme fodder, negative binomial regressions were used. For binary outcomes, logistic regression was employed, ${ }^{* * *} p<0.01,{ }^{* *} p<0.05,{ }^{*} p<0.1$

${ }^{\dagger}$ Variable used to create a cluster

${ }^{+{ }^{+}}$Livestock units based on Kazakh sheep units (sheep and goat $=1 \mathrm{LU}$, horse $=6 \mathrm{LU}$ and cattle $=5 \mathrm{LU}$ )

${ }^{a}$ Those with titles or contracts for pastureland indicating area only, $n=132$, no zeros

${ }^{\text {ax }}$ Sellers only, $N=48$, no zeros
}

larger of these groups partially compensate through lease of hay meadows. However, although differences in cropland access patterns between feeding strategy clusters are highly significant, there is no relationship between farm size and the probability of leasing this type of land (Table A3.2).

Although there are strong positive relationships between farm size and used land area, larger farms do not have access to greater areas per head of cattle and provide on average less fodder per head than smaller farms and households (Fig. 4a). This negative relationship is largely accounted for by self-produced roughage-the only fodder component for which regressions with cattle ownership are significant. In contrast, there are no relationships between farm size and frequency or mean concentrate provision, nor with overall ration quality (protein content) (Table 3, A3.2).

But differences in fodder ration composition and quality are evident between feeding strategy clusters (Table 3 , A1.2) and here cropland access appears important, as those with large land holdings (4 and 6) provide higher quality rations, with significant differences in particular with the large extensive fodder purchaser 5 . However, the overall negative relationship between fodder provision and size still applies-mean rations and arable land per head in the large fodder-producing cluster 6 are lower than those of smaller less mobile operations. Generally, forage is of poor quality, with silage little used amongst any group and natural hay more frequently provided than cultivated hay, which is usually lucerne or sainfoin and thus of much higher quality (Table A3.2).

In contrast to fodder ration composition, all indicators of pasture use and mobility exhibit a strong positive dependency on farm size (Table 3, A3.1). Only 28\% of households are mobile-using off-village pastures, but this is higher than for the small sedentary farm cluster, and the probability of mobility amongst farms increases strongly with both cattle and LU ownership. Whilst all mobile producers use remote pastures in summer, there is an important distinction between those who also use such off-village pastures in winter and those coming back to village pastures in that season, and this is also scale dependent. Larger operations require access to large high-quality grazing areas in spring, winter and autumn which cannot be provided by village pastures alone. Accordingly, both types of large farm (clusters 5 and 6) tend to use remote areas in summer and winter and, of the size quartiles, Q4 is the only group in which a majority are away from village pastures all year around (Table A3.1). Large farms have outlying bases in wintering areas, with houses (zimovki) and barns (pictured in Fig. $3 \mathrm{~b}$ ), but it should be noted that around $5 \%$ of farms, covering a range of sizes, located at such bases all year around, and is thus sedentary but located away from village pastures. There are also some differences between clusters covering similar size ranges: although the modal pattern for all three medium clusters concerns a single move to remote summer pastures, cluster 2 (medium mobile) is more likely to use both winter and summer pastures and provides less fodder on average than the other two medium-sized operations. There is a strong relationship between farm size and the probability of having some kind of leasehold contract for pastureland (Table A1.2), but none with lease area per head of livestock (Table 3). This may be due to the loose correspondence between areas specified in contracts and those 


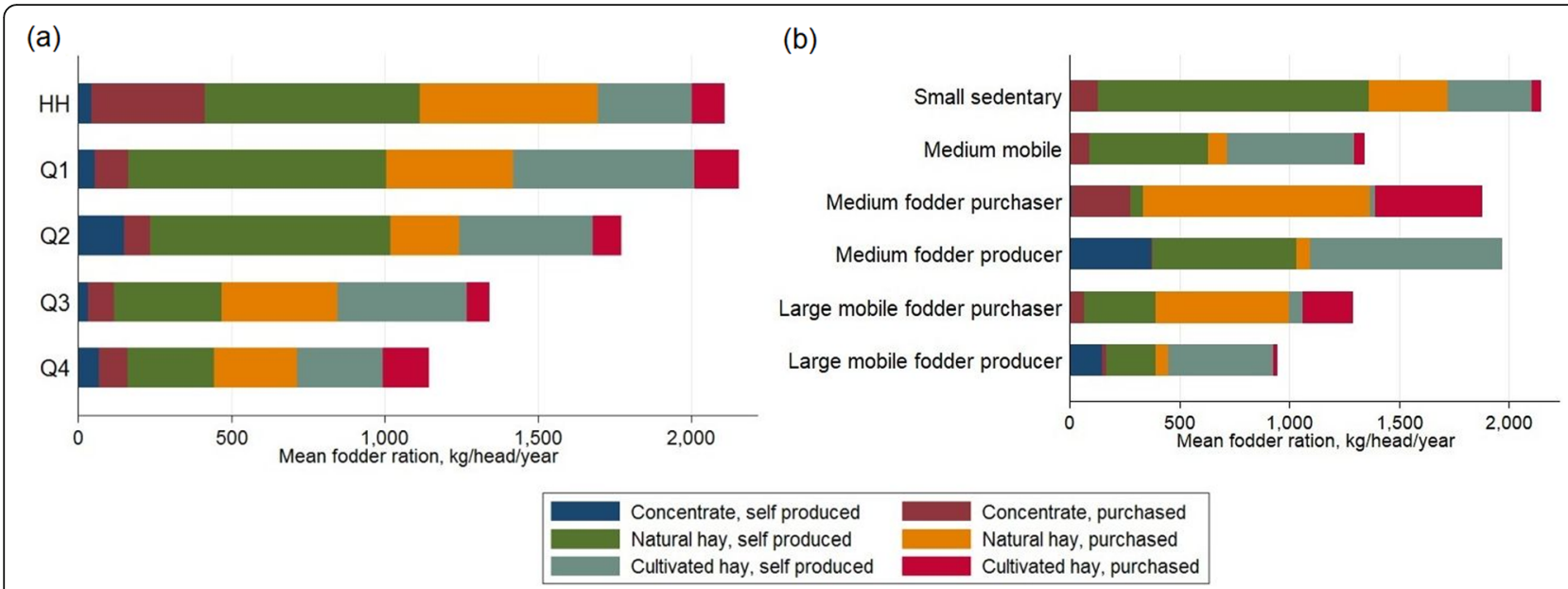

Fig. 4 Summary of mean supplement rations for cattle (means include zeros). a Households and farm size quartiles. b Feeding strategy cluster

actually used, as stock may range much further and their owners also access additional areas informally.

Overall then, farm scale is strongly linked to grazing behaviour, but more loosely related to supplement provision and provenance. It is also important to note that, within individual herds, feeding practices may vary widely. Interviews suggested that both medium fodder producers and purchasers often fatten a subset of their animals-usually concerning bullocks returning from the jailau or even stall-fed from birth, whilst cows may receive significantly lower rations. Notably, the largest farm in the sample, holding 3000 sheep, 125 cattle and 50 horses, relied largely on pasture for these animals, but also ran a large feedlot based on bullocks sourced from the farm's own grassraised cows and purchased animals. These were fed on bran purchased from Kostanai and Karaganda, financed each year through subsidies and sale of sheep-illustrating the importance of diversification. There is no other large farmer-feedlot like this in the sample, and the story of this farmer includes entry to the sector from outside livestock production, large amounts of credit and the receipt of almost every type of subsidy available to livestock producers. Other very large operations, notably in cluster 5 , tended to focus on raising large numbers, selling them off the jailau rather than investing in fodder production and fattening, which they considered appropriate only for small farms. This can be contrasted with a medium fodder purchaser (cluster 3) in a large settlement close to Almaty, whose small feedlot supplements other sources of income. For this producer, village pasture is sufficient to produce calves, which are entirely stall-fed from birth on purchased feed. Without access to distant pastures or leased arable land, such an enterprise of necessity remains small, but viable.

\section{Commercialisation, sales and animal performance}

As would be expected, both the mean volume and probability of cattle sales increase with farm size (Table 3, A3.3). Amongst feeding strategy clusters, annual sales range from 1 to 17 head and only one farm sold over 40 cattle during the survey period. Very few cattle are sold outside the two major channels of traders and bazaars, which do not differ remarkably with farm size or feeding strategy (Tables A3.4 \& A3.5, Supplementary materials). There are significant differences between district bazaars like that in Kegen, where capacity is small and sales mostly made farmer-to-farmer, and larger bazaars close to Almaty where buyers include wholesalers, abattoirs and fatteners. The cost of transport of livestock to distant markets was a significant problem mentioned by interviewees, especially those in Raiymbek where there is no livestock market. However, the overall probability of cattle sales occurring over the year is not related to distance from Almaty (Table A3.6), thanks in part to the distant reach of mobile traders (Table A3.7). Beef, also sold largely through traders and bazaars, is less commonly sold than live animals as slaughter and marketing entail greater costs and hygiene requirements. Those selling this product are concentrated in the large fodder-producing cluster (6), whilst live animal sales are both most likely (Table 3) and highest in volume (Table A3.3) in the large mobile fodder-purchasing cluster 5 . Of the medium clusters, cluster 3 (fodder purchaser) is no less commercially oriented than the other two medium groups, despite poorer access to land.

In Kazakhstan as a whole, the average carcass weights of cattle at sale were around $175 \mathrm{~kg}$ in 2018 (FAOSTAT) and the survey data reflect this, with mean weights lower than this figure amongst households and higher amongst individual farmers. The data suggest a significant positive relationship between farm size and cattle weights at sale (Table A3.3, supplementary material). However, this pattern is 
partially related to age at sale, which also increases with farm size. Households in particular tend to sell cattle young (mean age of 16 months) and, along with smaller farms, are most likely to state that animals lose weight over winter. There is a significant negative relationship between farm size and the probability of considering fodder insufficient, which may determine age and weight at sale (Table A3.3).

Bullocks were the most commonly sold, and relatively low variability in age at sale for this group suggests that the positive relationship between weight at sale and farm size is likely to be related to feeding rather than age (Table 3). Large mobile fodder producers (cluster 6) with access to both arable land and pastures have the highest carcass weights at sale and, as would be expected, the worst performing animals are the small sedentary group (cluster 1), which also provide poor-quality supplements dominated by natural hay (Table 3, Fig. 4b). Large extensive producers (5), despite good pasture access, sell at relatively low weights but sell on average more animals (Table A3.3). Although the overall quantity and composition of supplementary feed may be important, from interviews it became clear that some of the difference in sales weight may depend on whether supplements are used to keep animals in good condition during severe periods or to intensively fatten a small number before sale. In contrast to live cattle and beef, milk sales are not related to farm size. Raw milk may be purchased in small quantities by wholesale traders from smallholders and thus smaller producers are just as likely to sell. Amongst farms, distance from Almaty is negatively related to the probability of selling milk, and sellers are concentrated in Enbekshikazakh district where there are collection schemes from large companies such as Food Master (Table A3.6). Some in Kegen district have attempted to overcome market distance restrictions through the establishment of village collection points and coolers, through cooperative structures. There are subsidies for this but bureaucratic difficulties and conditions such as direct sales to processors hamper receipt. Sales of processed milk products, less perishable and actively marketed by farm members, display no relationship to distance from Almaty (Table A3.6) and are more likely to be marketed by larger farms (Table 3). Mean milk yields are extremely low, at around $850 \mathrm{l}$ per year for farms (Table A3.3), although they are around $1000 \mathrm{l}$ for the smaller numbers who sell this product. Slight increases in yields with farm size are not significant but there are larger differences between farms and households. These observations reflect the specialisation of this region in meat production, whilst large modern dairy plants tend to be located much closer to Almaty.

Concerning vertical coordination in the beef sector, no 2018 survey respondent sold to a processor, but in the 2019 interviews, the large farm-feedlot operation mentioned above had concluded a contract with a meat processor, opening eligibility for the meat output subsidy. Only one survey respondent sold directly to a feedlot (Table A3.4). However, interviews at bazaars suggested that many animals sold to traders are eventually purchased by fattening enterprises of various types. These range from small operations finishing a few animals at home to slaugherhouses acting as brokers, sending large numbers for fattening in Turkestan province. Beef value chains were found to be extremely long, including traders, bazaars, transport of cattle to other provinces for fattening and re-sale back to Almaty. Only two interviewees sold on contract, one with the meat processor as mentioned above and one with a wholesaler.

\section{Genetic improvement, mechanisation and investment}

Having explored grazing and feeding patterns, we now turn to other aspects of intensification and commercialisation: genetic improvement, on-farm investment and mechanisation, of which farm scale is clearly a major determinant (Table 4). One pathway to genetic improvement is participation in the government's Sybagha programme, ${ }^{3}$ which subsidises the cost of pedigree bulls at $50 \%$ of purchase cost or up to 150,000 KZT (350 USD at time of interviews), linked to additional payments per cow and calf associated with the bull. In our dataset, access to this programme is limited to the largest farms, but others also attempt to improve performance using locally available bulls, most of which are self-owned Aiylikul, Alatoo, white head or Angus breeds. Artificial insemination is unusual but most commonly used by smaller farms and households. Taking all forms of genetic improvement, around $20 \%$ of farmers use at least one method, a frequency which is much higher amongst larger farms (Table 4). The propensity to use pedigree animals is similar amongst both types of large farm (clusters 5 and 6), despite differences in winter feeding. Assessments of the outcomes of investments in highperforming pedigree breeds are not available but it seems possible that outcomes may be fairly poor amongst cluster 5 , given the feeding and husbandry conditions under which these animals are kept.

Pedigree bulls were by far the most commonly accessed subsidy. Others include machinery leasing (a mixture of subsidy and loan, accessed by $3 \%$ of farms) and output subsidies (by 1\%), also accruing to the largest farmers. The large farm-feedlot received both meat output subsidies and subsidies for fattening; the owner stated that crucial to the success of his operation was the ability of younger educated family members to understand the subsidy system, and the resources to invest in the infrastructure required to maximise benefits from this source. Difficulties obtaining subsidies were mentioned in almost every qualitative

\footnotetext{
${ }^{3}$ http://sybaga.kz/Home/Index
} 
Table 4 Genetic improvement, subsidies and credit in feeding strategy clusters and households

\begin{tabular}{|c|c|c|c|c|c|c|c|c|c|c|}
\hline Cluster & $\mathrm{HH}$ & $\begin{array}{l}\text { 1: small } \\
\text { sedentary }\end{array}$ & $\begin{array}{l}\text { 2: } \\
\text { medium } \\
\text { mobile }\end{array}$ & $\begin{array}{l}\text { 3: medium } \\
\text { fodder } \\
\text { purchaser }\end{array}$ & $\begin{array}{l}\text { 4: medium } \\
\text { fodder } \\
\text { producer }\end{array}$ & $\begin{array}{l}\text { 5: large } \\
\text { mobile fodder } \\
\text { purchaser }\end{array}$ & $\begin{array}{l}\text { 6: large } \\
\text { mobile } \\
\text { fodder } \\
\text { producer }\end{array}$ & $\begin{array}{l}\text { Total } \\
\text { farms }\end{array}$ & $\begin{array}{l}\text { Pearson's } \\
\text { chi-squared }_{\text {test }^{\#}}\end{array}$ & $\begin{array}{l}\text { Logistic } \\
\text { regression } \\
\text { Incattle }^{\mathbf{a}}\end{array}$ \\
\hline$N$ & 50 & 40 & 56 & 25 & 32 & 27 & 20 & 200 & $x^{2}$ & $\beta$ \\
\hline $\begin{array}{l}\text { Any kind of } \\
\text { genetic } \\
\text { improvement (0/1) }\end{array}$ & 0.14 & $0.03^{-c V}$ & 0.11 & 0.16 & 0.13 & $0.56^{+c v}$ & $55^{+C V}$ & 0.20 & $46.6^{* * *}$ & $1.83^{* * *}$ \\
\hline $\begin{array}{l}\text { Uses any type of } \\
\text { pedigree bull }(0 / 1)\end{array}$ & 0.10 & $0^{-c v}$ & 0.11 & $0.12^{-\mathrm{cv}}$ & 0.09 & $0.44^{+c v}$ & $50^{+C v}$ & 0.17 & $41.0^{* * *}$ & $1.97^{* * *}$ \\
\hline $\begin{array}{l}\text { Uses artificial } \\
\text { insemination }(0 / 1)\end{array}$ & 0.04 & 0.03 & 0 & 0.04 & 0.03 & 0.04 & 0 & 0.02 & 2.7 & -0.70 \\
\hline $\begin{array}{l}\text { Has subsidised bull } \\
(0 / 1)\end{array}$ & 0 & 0 & 0 & 0 & 0 & $0.22^{+c v}$ & $30^{+c v}$ & 0.06 & $42.8^{* * *}$ & $3.37^{* * *}$ \\
\hline $\begin{array}{l}\text { Received any } \\
\text { subsidy }(0 / 1)\end{array}$ & 0 & 0 & 0.02 & 0 & 0.06 & $0.33^{+c v}$ & $30^{+c v}$ & 0.09 & $40.6^{* * *}$ & $2.17^{* * *}$ \\
\hline $\begin{array}{l}\text { Received } \text { credit }^{\dagger} \\
(0 / 1)\end{array}$ & 0.14 & 0.1 & 0.07 & 0.24 & 0.13 & 0.19 & 0.20 & 0.14 & 6.1 & $0.44^{* *}$ \\
\hline $\begin{array}{l}\text { Used loan for } \\
\text { investment in } \\
\text { agriculture }(0 / 1)\end{array}$ & 0 & 0.03 & 0 & 0.12 & 0.03 & 0.07 & 0.10 & 0.04 & 8.4 & $0.85^{* * *}$ \\
\hline $\begin{array}{l}\text { Invested in barn/ } \\
\text { pasture use }(0 / 1)\end{array}$ & 0.04 & 0.05 & 0.11 & 0.24 & 0.13 & 0.26 & 0.25 & 0.15 & $9.8^{*}$ & $0.37^{*}$ \\
\hline $\begin{array}{l}\text { Invested in fodder } \\
\text { production }(0 / 1)\end{array}$ & 0 & 0 & 0.05 & 0 & 0.03 & 0.04 & 0.05 & 0.03 & 3.4 & 0.60 \\
\hline $\begin{array}{l}\text { Cooperative } \\
\text { member }(0 / 1)\end{array}$ & 0.04 & 0 & 0.05 & 0.08 & 0.03 & 0.04 & $0.20^{+c v}$ & 0.06 & $11.2^{* *}$ & $0.53^{*}$ \\
\hline Uses tractor $(0 / 1)$ & 0.34 & 0.57 & 0.54 & $0.24^{-\mathrm{cv}}$ & 0.66 & 0.70 & 0.80 & 0.57 & $18.7^{* * *}$ & $0.49^{* * *}$ \\
\hline $\begin{array}{l}\text { Uses mechanical } \\
\text { mower }(0 / 1)\end{array}$ & 0.16 & 0.40 & 0.41 & $0.16^{\mathrm{cv}}$ & 0.56 & 0.48 & $0.80^{+c v}$ & 0.45 & $20.9^{* * *}$ & $0.41^{* *}$ \\
\hline
\end{tabular}

${ }^{\dagger}$ Over past 3 years to the survey (otherwise all figures for 12 months to survey).

"Test statistic for the difference between farm clusters: ${ }^{* * *} p<0.01,{ }^{* *} p<0.05,{ }^{*} p<0.1$

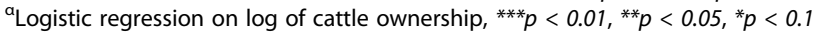

interview. Conditions such as minimum head of cows for the bull subsidy, head of bullocks for the fattening subsidy (400 head at the time of interviews) and liveweights $(400 \mathrm{~kg})$ for the meat output subsidy cut many people out and have also led to rent seeking by the processors or fattening enterprises to which animals must be sold-some of whom charge for the proof-of-sale documents required to obtain the subsidy. All farms outside Q4 are theoretically ineligible for bulls, lacking the 30 cows necessary to apply (see herd-size ranges for quartiles in Table A3.1). But administrative barriers and associated costs are also considered highly significant by farmers. Information is a serious problem, springing from a combination of complex application procedures and a lack of requisite agricultural extension services to accompany them. A number of interviewees mentioned applying through a paid intermediary for this reason and the (perceived) need for such an intermediary was one reason given for non-application.

The Government of Kazakhstan has attempted to broaden subsidy receipt to smaller farmers by offering them through cooperatives in which members can pool resources and apply for specially targeted subsidies with relaxed conditions. For example, weight at sale may be lower for cooperatives receiving the bullock-fattening subsidy, whilst members can pool cows in order to apply for the pedigree bull subsidy (Government of Kazakhstan 2017). In the survey, cooperative members appeared in all farm-scale quartiles, but most are large farms, in particular large fodder-producing cluster 6. Although subsidies for milk cooling and slaughtering equipment are available for cooperatives, interviewees engaging in these activities had not accessed them, although they were aware of their existence. Several mentioned that they had attempted to form a cooperative but had abandoned the process due to complexity.

Credit is more equitably accessed (although still positively related to farm size, Table 4), but is unlikely to be used for investment by households and small farms, which may employ loans for recurrent costs or outside agriculture. Lack of collateral was a commonly mentioned constraint, as this is usually accepted only as buildings, which are worth little in rural areas. Other than livestock, the 
most common investments are made in infrastructure such as winter houses, electricity and barns-most of which are likely to be associated with pasture use (Table 4, Figure A3.1, Supplementary Materials), again underlining the importance of wintering areas for larger farms. Investments in fodder production were less common, but clearly larger farms are more mechanised than smaller ones (Table 4). Within large farms, as would be expected, the large fodder-producing cluster is far more mechanised than the large fodder purchaser.

\section{Determinants of farm size and feeding strategy: geography and land access}

Both membership of the feeding strategy cluster and farm size can be related to a number of geographical and historical factors (Table 5). Farms in Enbekshikazakh provide on average double the concentrate amounts of farms in the other two districts-in which proximity to arable land areas and Almaty may both play a role (Table A3.8 Supplementary Materials). In contrast, average livestock unit ownership in more peripheral Kegen, which has the largest amount of pasture per farm, is around three times that of Raiymbek and twice that of Enbekshikazakh (Table A3.10, Supplementary Materials). Thus, the feeding strategy group most dependent on purchased feed (cluster 3) is concentrated in Enbekshikazakh district and in larger villages, whilst large extensive operations (cluster 5) are disproportionally found in Kegen (Table 5).

Another key factor affecting feeding strategy is whether the farm head worked on a kolkhoz or sovkhoz in the 1990s, which may have facilitated early receipt of land. ${ }^{4}$ Farm heads in the large mobile fodder-purchasing cluster (5) are the least likely to have been state or collective farm employees. Many in this group came to livestock production from other professions or arrived from China as part of the Kazakh 'oralman' (repatriation) programme, which provides support for Kazakh diaspora to settle in Kazakhstan (Cerny 2010). They therefore had to acquire both land and herds from scratch. In contrast, members of the fodder-producing group of large farms (cluster 6) are most likely to have been farm workers during the Soviet period and to have an agricultural education.

Because access to land and pasture is so determinant for farm characteristics and outcomes, we investigate this in more detail, looking at variability in land tenure arrangements (outside kitchen gardens) with feeding strategy cluster and farm scale (see Table A3.2).

\footnotetext{
${ }^{4}$ And indeed the probability of leasing any cropland outside kitchen gardens is strongly related to having worked for a state or collective farm (Pearson's $\left.X^{2}=7.2^{* * *}\right)$. The same is not true for hayland or pasture.
}

Concerning crop and hayland outside kitchen gardens, the majority of users have direct contracts with the state. Only $12 \%$ sublease any crop or hayland (the probability of which exhibits a weak positive relationship with cattle holdings in the case of hayland Table A2.2). The main fodder-producing clusters (4 and 6) are most likely to have 49-year leaseholds over cropland. But as this is the major path to land acquisition of any type, any links with feeding intensity may have more to do with the ability to acquire any land at all, than to differences in tenure security. Whilst those coming late to farming would not have been eligible for shares, some interviewees (particularly in cluster 3) did work for state farms and believed that they should have received land. Not every member of this cluster is located close to arable land or fodder markets, and for such farms, fodder purchase is a heavy financial burden and acquisition of additional land a pressing concern. However, interviews suggest that resource-poor farms such as those in cluster 3 are likely to have additional sources of income.

The 49-year lease over pasture dominates amongst larger farms and on winter pastures (Fig. 5b). This could be due to a need for tenure security, as investments in accommodation for people and animals are required in these areas. Another reason could be that the forest and common lands upon which more accessible tenure arrangements exist are mostly located in summer areas (Fig. 5a). In summer, short-term lease of forestry department land is common and easier to obtain (but less secure and shorter term) than long-term state leaseholds. Some in Enbekshikazakh district use remote pasture in the state reserve, set aside by the local government for common use. However, the availability of this land does not seem to have increased access to summer pasture for small producers, as farmers in Q4 are most likely to use this resource and the overall probability of being mobile (whether in farms, or households) is no higher in Enbekshikazakh than in other districts (Table A3.8). Only the largest farms use other state reserve lands, reflecting the distance and inaccessibility of these areas. In contrast, pasture subleasing is negatively related to farm size (Table A2.2).

Many interviewees mentioned that obtaining new land, or even giving unwanted land back to the district for re-allocation, was extremely difficult as auctions are rarely held, participation is subject to many conditions, and the whole process suffers from a lack of transparency. For those in the medium fodderproducing group, many of whom have arable land, expansion. Depends on winter pastures, but these interviewees mentioned that only the most distant winter bases remain available for rent, lacking water supply, adjacent hayland and good pastures. 
Table 5 Geographical and historical factors associated with feeding strategy cluster

\begin{tabular}{|c|c|c|c|c|c|c|c|c|c|c|}
\hline \multicolumn{2}{|l|}{ Variable } & \multirow{2}{*}{$\begin{array}{l}\text { 1: small } \\
\text { sedentary } \\
40\end{array}$} & \multirow{2}{*}{$\begin{array}{l}\text { 2: medium } \\
\text { mobile } \\
56\end{array}$} & \multirow{2}{*}{$\begin{array}{l}\text { 3: medium } \\
\text { fodder } \\
\text { purchaser } \\
25\end{array}$} & \multirow{2}{*}{$\begin{array}{l}\text { 4: medium } \\
\text { fodder } \\
\text { producer } \\
32\end{array}$} & \multirow{2}{*}{$\begin{array}{l}\text { 5: large } \\
\text { mobile fodder } \\
\text { purchaser } \\
27\end{array}$} & \multirow{2}{*}{$\begin{array}{l}\text { 6: large } \\
\text { mobile fodder } \\
\text { producer } \\
20\end{array}$} & \multirow{2}{*}{$\begin{array}{l}\begin{array}{l}\text { Total } \\
\text { farms }\end{array} \\
200\end{array}$} & \multirow{2}{*}{$\begin{array}{l}\text { For } \\
\text { Pearson's } \\
X^{2 \#}\end{array}$} & \multirow{2}{*}{$\begin{array}{l}\beta \text { Incattle } \\
\beta\end{array}$} \\
\hline$N$ & & & & & & & & & & \\
\hline \multicolumn{2}{|c|}{ Worked on sovkhoz (1/0) } & 0.5 & 0.54 & 0.36 & 0.59 & $0.22^{-c v}$ & 0.65 & 0.48 & $13.3^{* *}$ & $-0.38^{* *}$ \\
\hline \multicolumn{2}{|c|}{ Agricultural education (1/0) } & 0.03 & 0.2 & 0 & 0.13 & 0.07 & 0.25 & 0.12 & $14.1^{* *}$ & 0.29 \\
\hline \multirow{3}{*}{$\begin{array}{l}\text { District of } \\
\text { residence }\end{array}$} & Enbek (1/0) & 0.15 & 0.09 & $0.44^{+c v}$ & 0.25 & 0.26 & 0.20 & 0.20 & $14.7^{* *}$ & 0.30 \\
\hline & Kegen $(1 / 0)$ & 0.15 & $0.07^{\mathrm{cv}}$ & 0.24 & 0.13 & $0.56^{+c v}$ & 0.25 & 0.20 & $29.4^{* * *}$ & $0.40^{* *}$ \\
\hline & $\begin{array}{l}\text { Raiymbek } \\
(1 / 0)\end{array}$ & 0.7 & 0.84 & 0.32 & 0.63 & 0.19 & 0.55 & 0.59 & $44.7^{* * *}$ & $-0.50^{* * *}$ \\
\hline \multicolumn{2}{|c|}{ Population of home villaget } & 47073 & 48433 & 915212 & 6254 & 7530 & 5849 & 6043 & $4.3^{* * *}$ & $660^{*}$ \\
\hline \multicolumn{2}{|c|}{ Distance from Almaty $(\mathrm{km})^{+\dagger}$} & 213 & 22953 & 1722 & 211 & 1722 & 200 & 205 & $5.6^{* * *}$ & $-12.88^{* * *}$ \\
\hline
\end{tabular}

${ }^{\dagger}$ From 2009 census

${ }^{+\dagger}$ Generated by straight line GIS distance tool-as crow flies

${ }^{\#}$ Continuous variables: OLS regressions with group as the categorial predictor. Statistic given is the $F$ ratio for the overall model $\left({ }^{* * *} p<0.01\right.$, ${ }^{* *} p<0.05,{ }^{*} p<0$ )

Superscripts 1, 2, 3, 4, 5 and 6 indicate groups to which difference is significantly different from zero at **p< 0.05 or lower using pairwise comparisons with

Bonferroni correction

\#Binary variables: Pearson's chi-squared test: ${ }^{* *} p<0.01,{ }^{* *} p<0.05,{ }^{*} p<0$

Superscript $+/-\mathrm{cv}$ for binary variables indicates those cells which have Pearson's residuals greater than the critical value with Bonferroni correction (+ or - 2.86), indicating contribution to $X^{2}$

${ }^{a}$ Continuous variables: OLS regression on log of cattle ownership; for binary variables: logistic regression

Notably, the largest farm in the sample, coming later to farming, was unable to gain individual tenure over pasture or arable land and built up a patchwork of arrangements including subleasing and unofficial use of abandoned parcels to gain access to the required land resources. This means that they are unable to invest in planting of perennial crops or to depend on access to jailau for weight gain of young cattle. It is for this reason that the farmer has invested in feedlot operations, dependent on purchased grain. Some oralman with no shares but having strong ambitions in livestock production were able to exploit a period during which pastures were plentiful, one interviewee acquiring both a 49-year leasehold in his municipality of residence, and making informal deals with other municipalities for additional reserve land. This can be contrasted with some longtime residents of the same municipality who realised too late the importance of gaining tenure over pastures and cannot now expand locally as all pastures are now occupied. Whilst some send stock to the jailau with leaseholders, others have been unable to conclude such arrangements or are not ready to entrust their animals in this way.
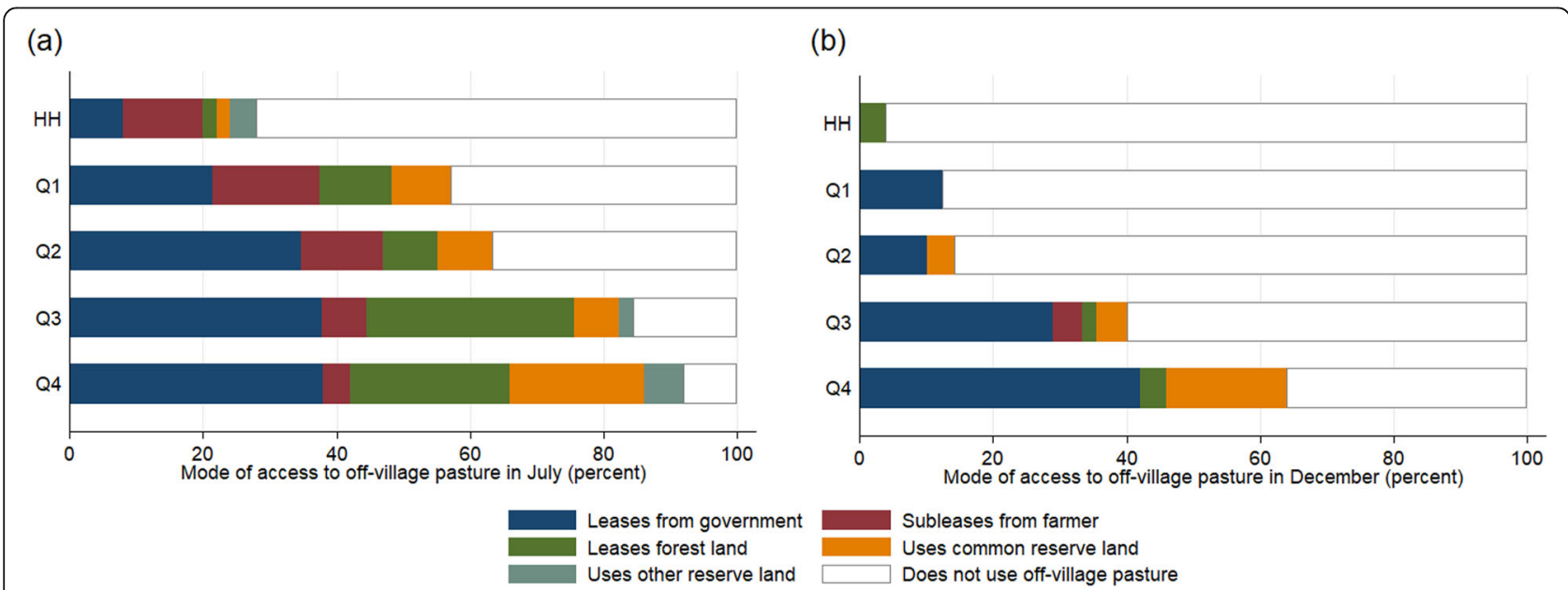

Fig. 5 Access to and property rights over off-village pasture by household and farm size quartile. a Summer. b Winter. Note that for a small proportion of farms, the same areas are used in both seasons 


\section{Discussion}

The analysis so far has presented the characteristics of livestock production for different types of farm, grouped by livestock ownership and production strategy. But what does this mean for the broader picture of livestock production in terms of the proportions of farms and the livestock and land held within them? Due to the way farms were sampled, the proportion of farms, livestock and land in each quartile or feeding strategy in the sample broadly represents that of the whole study area (Table 6). However, households were under-sampled in relation to farms. District statistics (Table 7) tell us the proportions of all cattle in farms and households in the study area, putting into perspective the relative importance of our farm clusters in terms of overall cattle populations.

\section{Limited specialisation within a diverse set of husbandry systems}

The farms studied here are not purely 'beef producers', as most own cattle, sheep and horses. Holding multiple species spreads both risk and income streams over the year, something commonly observed amongst livestock producers in many developing economies (Otte et al. 2012). With means of over 900 livestock units, the two large farm clusters clearly hold the bulk of livestock and land in the individual farm sample (Table 6), but taking the real proportion of household livestock into account (Table 7), these groups' share of total livestock populations would be far smaller. Meanwhile, the proportion of land they control would remain very high as households have so little of this asset. But as we have seen, there are different types of large farm, represented by feeding strategy clusters 5 and 6 . The largest proportion of cattle in the aggregate farm sample are held in large extensive operations producing little fodder themselves (cluster 5, Table 6). These producers provide mainly poor-quality roughage in winter and tend to sell large numbers of animals straight off summer pasture; cattle make a relatively low proportion of livestock units in their herds. The other large group (cluster 6), holding $27 \%$ of cattle in the farm sample, can be considered the most productive and commercially oriented, leasing large areas of arable land, employing mechanisation and selling cattle at high weights and most likely to sell beef. But access to winter pasture and associated infrastructure is a key characteristic of all large farms and both types are equally likely to use pedigree bulls, receive subsidies, apply for loans and make on-farm investments. Conversely, there is no relationship between cattle holdings and the probability of access to crop or hayland (Table A1.2).

Medium-sized farms have a wide range of grazing and feeding strategies, but the modal grazing pattern consists of remote pasture use in summer only, coming back to the village at winter. Of these, the fodder-purchasing cluster (3), making up $12 \%$ of the farm sample, holds virtually no arable land and is typically engaged in fattening a small number of head for sale. This group is disproportionally based close to Almaty or in larger communities. In contrast, medium landowners (4) provide the highest quantity and quantity of supplements of any group but have much poorer access to winter pasture than larger producers.

At the bottom end of the farm spectrum are the small sedentary cluster (1), making up around $20 \%$ of the farm sample with a mean of 97 livestock units and 4-5 head of cattle. They have the poorest access to pasture and provide the largest amounts of roughage to animals, most of which is self-produced. Members of this group tend to be located in smaller settlements and are unlikely to sell milk or to buy large amounts of concentrate.

Households are similar to the small sedentary group of farms, with poor access to off-village pasture, high probability of subleasing and low indicators of livestock performance. They hold around $60 \%$ of all cattle in the study area (Table 7).

Table 6 Proportions of feeding strategy cluster in the farm sample

\begin{tabular}{|c|c|c|c|c|c|c|c|}
\hline Cluster & $\begin{array}{l}\text { 1: small } \\
\text { sedentary }\end{array}$ & $\begin{array}{l}\text { 2: medium } \\
\text { mobile }\end{array}$ & $\begin{array}{l}\text { 3: medium } \\
\text { fodder purchaser }\end{array}$ & $\begin{array}{l}\text { 4: medium } \\
\text { fodder producer }\end{array}$ & $\begin{array}{l}\text { 5: large mobile } \\
\text { fodder purchaser }\end{array}$ & $\begin{array}{l}\text { 6: large mobile } \\
\text { fodder producer }\end{array}$ & Total \\
\hline$N$ & 40 & 56 & 25 & 32 & 27 & 20 & 200 \\
\hline Cattle & $7 \%$ & $15 \%$ & $8 \%$ & $8 \%$ & $35 \%$ & $27 \%$ & $100 \%$ \\
\hline Sheep and goats & $5 \%$ & $11 \%$ & $3 \%$ & $6 \%$ & $46 \%$ & $29 \%$ & $100 \%$ \\
\hline Livestock units & $6 \%$ & $13 \%$ & $5 \%$ & $7 \%$ & $40 \%$ & $29 \%$ & $100 \%$ \\
\hline Arable land & $4 \%$ & $16 \%$ & $1 \%$ & $34 \%$ & $1 \%$ & $43 \%$ & $100 \%$ \\
\hline Hayland & $10 \%$ & $22 \%$ & $2 \%$ & $18 \%$ & $24 \%$ & $24 \%$ & $100 \%$ \\
\hline Pasture & $4 \%$ & $20 \%$ & $1 \%$ & $6 \%$ & $42 \%$ & $27 \%$ & $100 \%$ \\
\hline
\end{tabular}


Table 7 Proportions of total district cattle populations held in farms and households

\begin{tabular}{lllll}
\hline Statistic & Cattle total (head) & In enterprises & In farms & In households \\
\hline Head of cattle & 121,982 & 7,048 & 42,357 & 72,577 \\
Proportion & $100 \%$ & $6 \%$ & $35 \%$ & $59 \%$ \\
\hline
\end{tabular}

Source: Local government statistics for the districts of (new) Raiymbek, Kegen and for the eastern sub-districts of Enbekshikazakh district included in the sample frame

\section{Livestock mobility as a key feeding strategy}

Despite the existence of different strategies in each farm size category, the outstanding pattern is a strong positive relationship between farm size and increasing reliance on pastures. Large farms tend to be no more specialised than other farms, whilst using more pasture and providing less fodder than smaller operations. This pattern resembles more the second scenario suggested in the aims of this study, in which larger producers are unspecialised, more dependent on pasture and more mobile. Many medium-sized farms fatten a small number of bullocks before sale, and the large fodder-producing group exhibits a number of intensification traits including breeding, improved ration quality and individual animal performance, and mechanisation of fodder production. But these large farms still provide, on average, less fodder per head of cattle than smaller, less commercial operations. The large fodder-purchasing cluster (5) has almost no cropland and provides little and poorquality fodder, yet this group represents the largest farms, selling the highest numbers of animals. Largescale farmer-feedlot operations do exist, raising cows on pasture and fattening large numbers of bullocks on purchased fodder. But these appear rare and benefit from high levels of subsidy which in turn are dependent on farm size and on the ability to invest in physical infrastructure for feedlots.

It could be that more intensive feeding is occurring higher up the value chain, but on this point, our results are inconclusive. There is little variability in market access and value chain participation between our diverse farm groups, with almost all selling live animals to traders, provincial or district markets. Although direct sales to feedlot enterprises are rare, traders may sell cattle on to such operations or fatten animals themselves at home. But these patterns cannot be described from household surveys as farmers are unaware of value chains beyond the initial sale. The main differences between farms in terms of market orientation are the propensity to sell milk amongst small farms and households located closest to Almaty, and that of the large fodderproducing cluster (6) to sell beef, but these are small effects and the majority of value from the sample is generated through sale of live animals. The lack of districtlevel facilities such as abattoirs or milk processors in Kegen and Narynkol is one reason for this, constituting an obstacle to sector development as a whole (Petrick et al. 2014).
Overall, securing access to winter pasture and to infrastructure such as wells and barns thereon appears to be both necessary for supporting large herds, and more readily available to larger farms. These pastures, characterised by semi-arid vegetation on snow-free southfacing slopes, are likely to offer forage resources superior to those of village pastures, and not only because they are more lightly grazed (Alimaev et al. 2008). It is for this reason that some livestock raisers are prepared to move their animals distances of up $200 \mathrm{~km}$ to use these pastures (Ferret 2018). But even this two-season migration is sub-optimal both for animal production and sustainable pasture management. Traditionally, and also in the Soviet period, a three-season migratory pattern was typical and is generally still considered ideal by interviewees. Only $9 \%$ of the farm sample follow this pattern, and some pastures previously set aside for use in spring and autumn only are now used by leaseholders for all seasons outside summer. Almost 30\% of farms are entirely sedentary, on village pasture or based at outlying farms.

Small sedentary farmers and many households are constrained to keep animals on village pastures all year-yet also lack means to provide high-quality feed. Figures for sedentarity amongst households and farms, combined with what we know about the overall proportions of animals in these entities (Table 7), suggest that roughly $45 \%$ of cattle in the study area are likely to be located on village pastures all year round-areas considered degraded by $56 \%$ of households and $31 \%$ of farms. Self-reported constraints to farm development reflect these patterns and are remarkably constant over scale and feeding strategy categories. Pasture access was the most commonly mentioned constraint, concerning over $30 \%$ of farms and households, followed by lack of land for fodder together with other issues with fodder (such as price), followed by financial barriers such as liquidity and credit.

\section{Conclusions and policy implications}

We analysed survey data and in-depth interviews from a livestock-producing area in south-eastern Kazakhstan to understand whether observed farming practices suggest the emergence of ranching and feedlots or whether more traditional and less intensive patterns of mobile animal husbandry dominate. We find that, rather than specialising and intensifying, larger livestock farms tend to be highly diversified in terms of stock species and are more 
mobile and provide fewer supplements per head than smaller farms. Winter pastures appear to be a key resource enabling growth. Many large farms have little access to cropland and provide low-quality supplements, although a subset with large cropland areas provide higher quality rations and fatten cattle before sale. Medium farms lack either winter pasture bases or cropland for growing supplements, but proximity to agricultural zones and markets may enable some to compensate through fodder purchases. Farmers' background and education, distance from markets and environmental conditions are factors affecting the observed production systems.

Almost half of cattle are found in sedentary households and farms, likely to contribute to land degradation around villages, which is severe in Kazakhstan (Alimaev et al. 2008). Most of these animals also receive lowquality supplements dominated by unimproved hays. The resulting poor animal productivity is likely to depress smallholder incomes and also results in high GHG emission intensity per unit of output. Provision of silage or quality hays such as lucerne and sainfoin finishing on grain and selling at an optimal age all improve feed conversion efficiency and help minimise GHG emission intensity (de Vries et al. 2015, Gerber et al. 2013), but these strategies depend largely on access to arable land, which is a limited resource. On the other hand, those farmers lacking arable land but which are highly mobile make efficient use of remote pastures without the opportunity costs of using arable land for feed.

The observed patterns thus stand in marked contrast to the allocation of production and processing across stages in the beef value chain, such as observed in the USA (Crespi and Saitone 2018). Livestock operations in our study site are much less specialised and often display low productivity levels. Beef value chains in the USA have been increasingly characterised by complex contracting arrangements between production stages that balance incentives and risks amongst the stakeholders (MacDonald and McBride 2009). In Kazakhstan, we observe much more informal contractual relations, lacking market transparency, incurring high transaction costs and displaying highly unequal access to publicly administered land and other resources. Current patterns of livestock husbandry appear to be strongly influenced by these conditions which prevent the realisation of the significant production potentials existing at the national scale (Hankerson et al. 2019).

Steps towards a more differentiated and productive cattle value chain will thus depend on more flexible and transparent access to key production factors for farmers and to downstream stages that add further value. Pathways to growth that would create synergies between an optimisation of grazing pressure, improvements to livestock productivity and smallholder incomes include a combination of improved land transferability, mechanisms for pasture tenure and management by smallholders, and growth of a vertically coordinated finishing industry. Government policies on subsidies, cooperative support and infrastructure development can be improved to meet these objectives (see also Petrick et al. 2018). We now go on to discuss these policy measures in detail.

\section{Land transfer, exchange and subleasing}

At the root of many constraints to growth identified in this study are issues with land markets and in particular the efficient transferability or exchange of land between farmers (Kvartiuk and Petrick 2021). Common to qualitative interviews with producers and administrators was the observation that other than auctions (which are both rare and incur high transaction costs) or subleasing (which is illegal although clearly tolerated), it is extremely difficult for farms to obtain new leaseholds or to exchange or divide leaseholds between farmers, even though clauses allowing direct alienation do exist in the Land Code. A number of interviewees even observed that it is almost impossible to give back unused land to district administrations for re-distribution because there is no operational mechanism for doing so. Yet according to the Kazakhstani government, large areas of leasehold land are unused or underused and an unknown amount is held by banks following debt default. Kazakhstan is currently planning to expropriate such land for redistribution, but this would be a short-term solution creating a single 'big bang' of land availability (Abzhekenova 2019, Ministry of Agriculture of the Republic of Kazakhstan 2018). A longer-term solution would be to facilitate leasehold exchange, formalise subleasing and create easier mechanisms (and incentives) to return underused land to districts.

\section{Pasture management}

Individualised tenure, combined with highly skewed ownership distributions in which the bulk of producers own few animals (Fig. 1), does not encourage the pooling of animals, which would be needed in order for smallholders to access distant pastures. Policy measures to encourage pasture use have included subsidies for water supply and winter houses in remote pastures and the introduction of a Law on Pastures in 2017. This law places responsibility for pasture management and planning on municipal governments and exhorts them to promote seasonality of pasture use and increase the mobility of livestock away from settlements. It also makes provisions for the voluntary association of pasture users and introduces stricter regulation of overstocked village pasturelands. However, it does not introduce alternative 
land access mechanisms to those specified in the 2003 Land Code, of which the 49-year leasehold is most common. Leaseholds are allocated through auction on a case-by-case basis, with no link to pasture planning processes. Thus, there is no mechanism to manage the resource at the ecosystem level, for example by ensuring that each producer has access to the optimal threeseason grazing system. The above-mentioned retrieval of unused leaseholds through expropriation may offer an increase in land availability, but if auction remains the only subsequent method of allocation, then it is unlikely that improved access for smallholders would result.

Alternatively, the expropriation process (and also natural leasehold expiry) could be an opportunity to establish specific areas for smallholders in seasonal pastures. Such areas would therefore have to be both large and accessible enough to be attractive to small farms and households, whilst infrastructure development may also increase the use of distant forest and state reserve pastures by larger farms. The promotion of collective institutions for management of these pastures could be envisaged, following models existing in France, Kyrgyzstan and Switzerland (Eychenne and Lazaro 2014, Kasymov and Thiel 2019, Stevenson 1991). In Kyrgyzstan, where many livestock raisers own few animals, collective herding is commonly employed to create economies of scale for use of remote pastures, either based on a rota system or by paying a professional shepherd (Steimann 2011). In Kazakhstan, group herding by rota $(k y z y k)$ does exist on village pastures but is unusual outside these areas. Meanwhile, the more formal pasture users' associations foreseen in the 2017 Law on Pastures do not yet appear to have emerged in reality.

\section{Finishing}

Synergies between improved smallholder incomes, livestock productivity and GHG emission reductions may be achieved through an increase of short-term animal finishing through feedlots (Ministry of Agriculture of the Republic of Kazakhstan 2018, Wilkes and Merger 2014). Our dataset suggests that livestock raisers either fatten animals themselves (usually concerning those either close to markets or having their own cropland) or provide minimum winter supplements, selling animals off the jailau to traders. These traders may in turn have their own small fattening operations or sell on to those that do, but direct sale by farmers to large industrial scale units is rare. Animals are more likely to be sent, via long chains of intermediaries, to feedlots in regions of the country where feed is cheap. The Kazakhstani government and private individuals have both invested in large industrial feedlots, but it is unclear whether these provide outlets for producers through vertical coordination. Vertically integrated operations may even compete with farmers for pasture. Capital-intensive integrated beef enterprises are said to be profitable only if a significant part of nutrition consists of grazing and feed prices are low (FAO Investment Centre 2010); some farmers may prefer to fatten their animals on summer pastures, so feedlots may be competitive buyers only in autumn (ibid). Notably, a number of interviewees noted that specialised credit lines for fattening which are not designed to include a grazing phase are unprofitable. Kazakhstan could look into mechanisms of linking beef producers to small and medium feedlots beyond the current output subsidies for direct sales to industrial operations (which currently benefit few producers due to weight and head conditions). More research on the economics of different finishing models should be conducted.

\section{Subsidies and cooperatives}

Conditions for subsidy receipt by farmers exclude the vast majority of livestock producers. To get around this problem, subsidies and loans have been made available for members of cooperatives who individually would not meet scale criteria for receipt. However, our results suggest that the complexity of application processes through cooperatives remains a barrier and that uptake was most common amongst the largest farmers-eligible for subsidies as individuals in any case. Subsidies aside, cooperatives have the potential to reduce transaction costs for marketing and improve access to credit, insurance and extension (OECD 2015, 2019). Whilst there was a burst of registration following improved legislation in 2015, it has been estimated that $60 \%$ of these are 'false' or inactive cooperatives existing solely to gain access to subsidies, whilst a true cooperative movement has yet to emerge (OECD 2019). In addition to simplifying registration procedures and providing education about the aims of service cooperatives, building on other collective action mechanisms has also been recommended (OECD 2015, Petrick et al. 2018) and could be applied to management of common pasture areas, processing and marketing.

\section{Study limitations and future research}

Whilst we gave a first overview of current cattle husbandry systems in one study site, we certainly cannot claim that these findings can be generalised for Kazakhstan as a whole. For example, beef production in the northern steppe zone is much more sedentary, perhaps due to harsher winters and lower environmental variability (Khanyari et al. 2021). More regionally differentiated studies would be necessary, including further downstream stages of the value chain. More rigorous empirical work should be carried out to shed light on the underlying drivers of herd growth and long-term 
dynamics of production systems. Our analysis here revealed little about the profitability of different production systems. This type of evidence will be required to come up with more accurate predictions concerning the further evolution of Kazakhstan's cattle sector. Whilst access to cropland and pasture will be crucial factors to consider locally, the costs and barriers of linking cattle farmers to supplementary concentrate, to finishing and ultimately to urban consumer demand, possibly across national borders, are likely to be equally decisive for further growth. At the same time, a broader assessment of existing production systems needs to explore the environmental impacts more deeply, such as with regard to nutrient and energy flows or GHG emissions. Likewise, the social and employment effects of a fundamental change in farming systems should be addressed by future analytical work.

\section{Supplementary Information}

The online version contains supplementary material available at https://doi. org/10.1186/s13570-021-00217-1.

Additional file 1. Supplementary Materials

\section{Acknowledgements}

In addition to our funders (listed above), we would like to thank BISAM in Almaty and in particular Serik Jaxylykov for managing the survey and supervising enumerators and all co-supervisors and enumerators who participated. We also thank Aiylym Sultankyzy at TALAP for the field translation of qualitative interviews and all the Kazakh livestock producers who so kindly gave their time for our inquiries.

\section{Authors' contributions}

SR: Led on drafting of the manuscript, questionnaire design, management of the survey pilot, qualitative interview process and data analysis.

ZB: With Kazakh ANICANET partner TALAP, participated in survey pilot, conducted qualitative interview process with SR and provided technical input on economics and policy in Kazakhstan livestock sector.

NM: Co-managed questionnaire piloting and provided input into the questionnaire design and data analysis.

ND: Participated in project conception at IAMO and provided input into the questionnaire design.

MP (principal investigator): Led project conception and design and participated in the questionnaire design, manuscript writing and data analysis.

The authors read and approved the final manuscript.

\section{Funding}

This study draws on outputs of the project "Revitalising animal husbandry in Central Asia: A five-country analysis (ANICANET)" (www.iamo.de/anicanet), funded by the German Federal Ministry of Education and Research (BMBF). Part of the work was supported by the German Academic Exchange Service (DAAD) from funds of the Federal Ministry for Economic Cooperation (BMZ), SDGnexus Network (grant number 57526248), program "exceed - Hochschulexzellenz in der Entwicklungszusammenarbeit." Open Access funding enabled and organized by Projekt DEAL.

\section{Availability of data and materials}

The datasets collected and analysed during the current study are available from the corresponding author on reasonable request.

\section{Declarations}

\section{Ethics approval and consent to participate}

The research included survey and interview data. All participants gave their informed consent to be interviewed. The database was entirely anonymised before analysis. The recommendation of the Head of Department is that ethical clearance from the IAMO Ethics Committee is not required, as the project does not raise any research ethics issues.

\section{Consent for publication}

Not applicable

\section{Competing interests}

The authors declare that they have no competing interests

\section{Author details}

${ }^{1}$ Justus Liebig University, Giessen, Germany. ${ }^{2} \mathrm{FAO}$ Kazakhstan, Nur-Sultan, Kazakhstan. ${ }^{3}$ Leibniz Institute of Agricultural Development in Transition Economies (IAMO), Halle, Germany.

Received: 6 August 2021 Accepted: 3 October 2021

Published online: 23 December 2021

\section{References}

Abzhekenova, N. 2019. Why does Kazakhstan propose to take back large territories from careless landusers? [Dlya chero $\vee$ Kazakhstane predlagaiut otbirat' ogromnye territorii u neradivykh zemlepol'zovatelei?]. Caravan, 19 March 2019.

AFRC Technical Committee on Responses to Nutrients. 1993. Energy and protein requirements of ruminants. $\mathrm{CAB}$ International.

Alimaev, I. I. 2003. Transhumant ecosystems: Fluctuations in seasonal pasture productivity. in C. Kerven, editor, Prospects for pastoralism in Kazakhstan and Turkmenistan: From state farms to private flocks. Routledge Curzon.

Alimaev, I.I., C. Kerven, A. Torekhanov, R. Behnke, K. Smailov, V. Yurchenko, Z. Sisatov, and K. Shanbaev. 2008. The impact of livestock grazing on soils and vegetation around settlements in southeast Kazakhstan. In The socioeconomic causes and consequences of desertification in Central Asia, ed. R. Behnke. Dordrecht: Springer. https://doi.org/10.1007/978-1-4020-8544-4_5.

Baltenweck, I., S. Staal, M. N. M. Ibrahim, M. Herrero, F. Holmann, M. Jabbar, V. Manyong, B.R. Patil, P. Thornton, T. Williams, M. Waithaka and T. d. Wolff. 2003. SLP project on transregional analysis of crop-livestock systems croplivestock intensification and interactions across three continents: Main report. International Livestock Research Institute (ILRI), International Centre for Tropical Agriculture (CIAT), International Institute of Tropical Agriculture (IITA), University of Peradeniya (Sri Lanka), BAIF (India), Nairobi.

Behnke, R. 2008. The drivers of fragmentation in arid and semi-arid landscapes. In Fragmentation in semi-arid and arid landscapes, ed. K. Galvin, R. Reid, R. Behnke, and N. Hobbs, 225-252. Heidelberg, Germany: Springer.

Behnke, R. 2021. Grazing into the Anthropocene or back to the future? Frontiers in Sustainable Food Systems 5. https://doi.org/10.3389/fsufs.2021.638806

Boone, R.B., and N.T. Hobbs. 2004. Lines around fragments: Effects of fencing on large herbivores. African Journal of Range and Forage Science 21 (3): 147-158. https://doi.org/10.2989/10220110409485847.

Broka, S., A. Giertz, G. Christensen, D. Rasmussen, A. Morgounov, T. Fileccia, and R. Rubaiza. 2016. Kazakhstan agricultural sector risk assessment. In 103076-KZ. Washington DC: World Bank. https://doi.org/10.1596/23763.

Cerny, A. 2010. Going where the grass is greener: China Kazaks and the Oralman immigration policy in Kazakhstan. Pastoralism 1 (2).

Crespi, J.M., and T.L. Saitone. 2019. Are cattle markets the last frontier? Vertical coordination in animal-based procurement markets. Annual Review of Resource Economics 10 (1): 207-227.

Davis, K.F., K. Yu, M. Herrero, P. Havlik, J.A. Carr, and P. D'Odorico. 2015. Historical trade-offs of livestock's environmental impacts. Environmental Research Letters 10 (12). https://doi.org/10.1088/1748-9326/10/12/125013.

de Vries, M., C.E. van Middelaar, and I.J.M. de Boer. 2015. Comparing environmental impacts of beef production systems: A review of life cycle assessments. Livestock Science 178: 279-288. https://doi.org/10.1016/j.livsci.2 015.06.020.

Delgado, C. L., C. A. Narrod and M. M. Tiongco. 2008. Determinants and implications of the growing scale of livestock farms in four fast-growing developing countries. IFPRI research report 157. 
Djanibekov, N., and M. Petrick. 2020. Statistical data on farming structures, land use and agricultural output for provinces in five Central Asian countries 1992-2015 [database]. Cologne: GESIS Data Archive https://doi. org/10.7802/2008.

Dong, S., L. Wen, S. Liu, X. Zhang, J.P. Lassoie, S. Yi, X. Li, J. Li, and Y. Li. 2011. Vulnerability of worldwide pastoralism to global change and interdisciplinary strategies for sustainable pastoralism. Ecology and Society 16 (2): 10. https:// doi.org/10.5751/ES-04093-160210.

Everitt, B.S., S. Laundau, M. Leese, and D. Stahl. 2011. Cluster analysis. Wiley. https://doi.org/10.1002/9780470977811.

Eychenne, C., and L. Lazaro. 2014. Summer pastures: Between "commons" and "public goods". Journal of Alpine Research 102 (2). https://doi.org/10.4000/rga.2303.

FAO. 2013. Irrigation in Central Asia in figures. In AQUASTAT Survey-2012. FAO: Rome.

FAO Investment Centre. 2010. Highlights on four livestock sub-sectors in Kazakhstan: Meat. Rome: FAO.

FAOSTAT. 2021. Food and Agriculture Organisation of the United Nations Statistics Database. Rome: Food and Agriculture Organization of the United Nations http://faostat.fao.org/.

Fedorovich, B.A. 1973. Natural conditions of the arid zones of the USSR and ways of development of their livestock sectors [Prirodnye usloviya aridnykh zon SSSR i puti razvitiya $\vee$ nikh zhivotnovodsva]. In Essays on the agricultural history of the peoples of Central Asia and Kazakhstan [Ocherki po Istorii Khozyaistva Narodov Srednei Asii i Kazakhstana], ed. S.M. Abramov and A. Orazov, 207-222. Leningrad: Nauka.

Fernández-Giménez, M.E., and J. Ritten. 2020. An economic analysis of transhumance in the Central Spanish Pyrenees. Pastoralism Journal 10 (10). https://doi.org/10.1186/s13570-020-00163-4.

Ferret, C. 2018. Mobile pastoralism a century apart: Continuity and change in south-eastern Kazakhstan, 1910 and 2012. Central Asian Survey 37 (4): 503525. https://doi.org/10.1080/02634937.2018.1484698.

García-Martínez, A., A. Olaizola, and A. Bernués. 2009. Trajectories of evolution and drivers of change in European mountain cattle farming systems. Animal 3 (1): 152-165. https://doi.org/10.1017/S1751731108003297.

Gerber, P.J., H. Steinfeld, B. Henderson, A. Mottet, C. Opio, J. Dijkman, A. Falcucci, and G. Tempio. 2013. Tackling climate change through livestock - A global assessment of emissions and mitigation opportunities. Rome: FAO.

Government of Kazakhstan. 2017. On approval of the rules for subsidizing the development of livestock breeding, improving the productivity and quality of livestock products [Ob utverzhdenii pravil subsidirovaniya razvitiya plemennogo zhivotnovodstva, povysheniya produktivnosti i kachestva produktsii zhivotnobodstva]. in Order of the Deputy Prime Minister of the Republic of Kazakhstan - Minister of Agriculture of the Republic of Kazakhstan. Registered with the Ministry of Justice of the Republic of Kazakhstan on February 17, 2017 No. 14813 Astana.

Green, J.A. 2021. Too many zeros and/or highly skewed? A tutorial on modelling health behaviour as count data with Poisson and negative binomial regression. Health Psychology and Behavioural Medicine 9 (1): 436-455. https://doi.org/10.1080/21642850.2021.1920416.

Hankerson, B.R., F. Schierhorn, A.V. Prishchepov, C. Dong, C. Eisfelder, and D. Müller. 2019. Modeling the spatial distribution of grazing intensity in Kazakhstan. PLoS ONE 14 (1): 1-27. https://doi.org/10.1371/journal.pone.0210051.

Herrero, M., S. Wirsenius, B.H.C. Rigolot, P. Thornton, P. Havlik, I. de Boer, and P.J. Gerber. 2015. Livestock and the environment: What have we learned in the past decade? Annual Review of Environment and Resources 40 (1): 177-202. https://doi.org/10.1146/annurev-environ-031113-093503.

Huntsinger, L., L.C. Forero, and A. Sulak. 2010. Transhumance and pastoralist resiliance in the Western United States. Pastoralism Journal 1 (1): 9-36.

Issayeva, Z.B., and A.S. Bakhralinova. 2020. Ecosystem approach of natural pastures in their seasonal use in Zhambyl region. News Of The National Academy Of Sciences of The Republic Of Kazakhstan Series of Agricultural Sciences 3 (57): 5-12. https://doi.org/10.32014/2020.2224-52 6X.19.

Kanter, D., M. Musumba, S.L.R. Wood, C. Palm, J. Antle, P. Balvanera, V.H. Dale, P. Havlik, K.L. Kline, R.J. Scholes, P. Thornton, P. Tittonell, and S. Andelman. 2016. Evaluating agricultural trade-offs in the age of sustainable development. Agricultural Systems 163: 73-88. https://doi. org/10.1016/j.agsy.2016.09.010.

Kasymov, U., and A. Thiel. 2019. Understanding the role of power in changes to pastoral institutions in Kyrgyzstan. International Journal of the Commons 13 (2): 931-948. https://doi.org/10.5334/ijc.870.
Kazakhstan Statistical Agency. 2014. Agriculture, forests and fishing in the Republic of Kazakhstan 2009-2013 [Sel'skoe, Lesnoe i Rybnoe Khozyaistvo v Respubliki Kazakhstan]. Astana.

Kerven, C., I.I. Alimaev, R. Behnke, G. Davidson, L. Franchois, N. Malmakov, E. Mathijs, A. Smailov, S. Temirbekov, and I.A. Wright. 2004. Retraction and expansion of flock mobility in Central Asia: Costs and consequences. African Journal of Range and Forage Science 21 (3): 91-102. https://doi.org/10.2989/1 0220110409485848

Kerven, C., S. Robinson, and R. Behnke. 2021. Pastoralism at scale on the Kazakh rangelands: From clans to workers to ranchers. Frontiers in Sustainable Food Systems 4 (298). https://doi.org/10.3389/fsufs.2020.590401.

Kerven, C., S. Robinson, R. Behnke, K. Kushenov, and E.J. Milner-Gulland. 2016. A pastoral frontier: From chaos to capitalism and the recolonisation of the Kazakh rangelands. Journal of Arid Environments 127: 106-119. https://doi. org/10.1016/j.jaridenv.2015.11.003.

Khanyari, M., S. Robinson, E.J.M.-G.A. Salemgareyev, and E.R. Morgan. 2021. Mapping relationships between multi-scale factors to explore ungulate health in a Central Asian rangeland. People and Nature forthcoming.

Klapwijk, C.J., M.T. van Wijk, T.S. Rosenstock, P.J.A. van Asten, P.K. Thornton, and K. E. Giller. 2014. Analysis of trade-offs in agricultural systems: Current status and way forward. Current Opinion in Environmental Sustainability 6: 110-115. https://doi.org/10.1016/j.cosust.2013.11.012.

Kvartiuk, V., and M. Petrick. 2021. Liberal land reform in Kazakhstan? The effect on land rental and credit markets. World Development 138. https://doi.org/10.101 6/j.worlddev.2020.105285

MacDonald, J.M., and W.D. McBride. 2009. Transformation of U.S. Livestock Agriculture Scale, Efficiency, and Risks. United States Department of Agriculture.

Makles, A. 2012. Stata tip 110: How to get the optimal k-means cluster solution. The Stata Journal 12 (2): 347-351. https://doi.org/10.1177/1536867X1201200213.

McAllister, R.R.J., I.J. Gordon, M.A. Janssen, and N. Abel. 2006. Pastoralist's responses to variation of rangeland resources in time and space. Ecological Applications 16 (2): 572-583. https://doi.org/10.1890/1051-0761(2006)01 6[0572:PRTVOR]2.0.CO;2.

McDermott, J. J., S. J. Staal, H. A. Freeman, M. Herrero and J. A. van de Steeg. 2010. Sustaining intensification of smallholder livestock systems in the tropics. Livestock Science 30: 95-109, 1-3, doi: https://doi.org/10.1016/ j.livsci.2010.02.014.

Milner-Gulland, E.J., C. Kerven, R. Behnke, I.A. Wright, and A. Smailov. 2006. A multi-agent system model of pastoralist behaviour in Kazakhstan. Ecological Complexity 3 (1): 23-36. https://doi.org/10.1016/j.ecocom.2005.05.004.

Ministry of Agriculture of the Republic of Kazakhstan. 2018. National plan of Kazakhstan's livestock sector development for 2018-2027. Astana.

Mirzabaev, A., M. Ahmed, J. Werner, J. Pender, and M. Louhaichi. 2016. Rangelands of Central Asia: Challenges and opportunities. Journal of Arid Lands 8 (1): 93-108. https://doi.org/10.1007/s40333-015-0057-5.

Mubiru, S.L., J.S. Tenywa, N. Halberg, D. Romney, W. Nanyeenya, I. Baltenweck, and S. Staal. 2007. Categorisation of dairy production systems: A strategy for targeting meaningful development of the systems in Uganda. Livestock Research for Rural Development 17 (7).

Nieto, M.I., O. Barrantes, L. Privitello, and R. Reiné. 2018. Effects of the management of extensive beef grazing systems on the mitigation of greenhouse gas emissions in semi-arid rangelands of central Argentina. Sustainability 10 (11). https://doi.org/10.3390/su10114228.

OECD. 2015. Strengthening Agricultural Co-operatives in Kazakhstan. Paris: OECD Publishing.

OECD. 2019. Monitoring the Development of Agricultural Co-operatives in Kazakhstan. Paris: OECD Publishing.

OECD. 2020. Kazakhstan. in Agricultural Policy Monitoring and Evaluation. Paris: OECD Publishing.

Oshakbayev, D., and J. Bozayeva. 2019. Kazakhstan country report prepared within the research project "ANICANET - Revitalizing Animal Husbandry In Central Asia: A Five-Country Analysis". Almaty: TALAP.

Otte, J., A. Costales, J. Dijkman, U. Pica-Ciamarra, T. Robinson, V. Ahuja, C. Ly, and D. Roland-Holst. 2012. Livestock Sector Development for Poverty Reduction: An Economic and Policy Perspective. Rome: FAO.

Petrick, M., D. Oshakbayev, and J. Wandel. 2014. Kazakhstan's wheat, beef and dairy sectors: An assessment of their development constraints and recent policy responses. IAMO Discussion Paper 145, Halle (Saale) (145).

Petrick, M., D. Raitzer, and S. Burkitbayeva. 2018. Policies to unlock Kazakhstan's agricultural potential. In Kazakhstan: Accelerating Economic Diversification, ed. 
K. Anderson, G. Capannelli, E. Ginting, and K. Taniguchi, 21-72. Manila, Phillipines: ADB.

Petrick, M. and L. Götz. 2019. Herd Growth, Farm Organisation and Subsidies in the Dairy Sector of Russia and Kazakhstan. Journal of Agricultural Economics 70 (3): 789-811.

Pomfret, R. 2013. Kazakhstan's Agriculture after Two Decades of Independence. Elliot School of International Affairs: George Washington University.

Reid, R., M.E. Fernandez-Gimenez, and K. Galvin. 2014. Dynamics and resilience of rangelands and pastoral peoples around the Globe. Annual Review of Environment and Resources 39 (1): 217-242. https://doi.org/10.1146/annurevenviron-020713-163329.

Robinson, S. 2020. Livestock in Central Asia: From rural subsistence to engine of growth? IAMO Discussion Paper 193. Halle: IAMO

Robinson, S., C. Kerven, R. Behnke, K. Kushenov, and E.J. Milner-Gulland. 2017. Pastoralists as optimal foragers? Reoccupation and site selection in the deserts of post-Soviet Kazakhstan. Human Ecology 45 (1): 5-21. https://doi. org/10.1007/s10745-016-9870-5.

Robinson, S., and E.J. Milner-Gulland. 2003a. Political change and factors limiting numbers of wild and domestic ungulates in Kazakhstan. Human Ecology 31 (1): 87-110. https://doi.org/10.1023/A:1022834224257.

Robinson, S., and E.J. Milner-Gulland. 2003b. Contraction in livestock mobility resulting from state farm re-organisation. In In From state farm to private flocks: Prospects for pastoralism in Kazakstan and Turkmenistan, ed. C. Kerven. London: Routledge Curzon Press.

Robinson, S., and M. Petrick. 2021. Trade-offs among sustainability goals in the Central Asian livestock sector: A research review. SDGnexus Network Working Paper No 1. Center for: International Development and Environmental Research (ZEU), Justus Liebig University Giessen, Giessen. http://dx.doi.org/1 0.22029/jupub-58.

Salmon, G., N. Teufel, I. Baltenweck, M.v. Wijk, L. Claessens, and K. Marshall. 2018. Trade-offs in livestock development at farm level: Different actors with different objectives. Global Food Security 17: 103-112. https://doi.org/10.1016/ j.gfs.2018.04.002.

Serneels, S., M. Herrero, S. BurnSilver, P.C. Trench, K. Cochrane, K. Homewood, P. Kristjanson, F. Nelson, M. Radeny, D.M. Thompson, and M.Y. Said. 2009. Methods in the analysis of Maasai livelihoods. In Staying Maasai? ed. K. Homewood, P. Kristjanson, and P.C. Trench, 43-67. New York: Springer. https://doi.org/10.1007/978-0-387-87492-0_2.

Sharpe, D. 2015. Chi-square test is statistically significant: Now what? Practical Assessment, Research and Evaluation 20 (8).

Solano, C., H. Leon, E. Perez, and M. Herrero. 2001. Characterising objective profiles of Costa Rican dairy farmers. Agricutural Systems 67 (3): 153-179. https://doi.org/10.1016/S0308-521X(00)00054-8.

Steimann, B. 2011. Making a Living in Uncertainty. Agro-Pastoral Livelihoods and Institutional Transformations in Post-Soviet Rural Kyrgyzstan. Bishkek and Zurich: University of Zurich.

Steinfeld, H., T. Wassenaar, and S. Jutzi. 2006. Livestock production systems in developing countries: Status, drivers, trends. Revue Scientifique Et Technique (International Office of Epizootics) 25 (2): 505-516. https://doi.org/10.20506/ rst.25.2.1677.

Stevenson, G.G. 1991. Common Property Economics. A general theory and land use applications: Cambridge University Press, Cambridge. https://doi.org/10.1017/ CBO9780511528361.

St-Pierre, A.P., V. Shikon, and D.C. Schneider. 2018. Count data in biology-Data transformation or model reformation? Ecology and Evolution 8 (6): 30773085. https://doi.org/10.1002/ece3.3807.

Suleimenov, M., and P. Oram. 2000. Trends in feed, livestock production and rangelands during the transition period in three Central Asian countries. Food Policy 25 (6): 681-700. https://doi.org/10.1016/50306-9192(00)00037-3.

UNFCCC. 2019. Greenhouse Gas Inventory Data - Detailed data by Party. Updated November 2019. Accessed November 2020. https://di.unfccc.int/detailed_da ta_by_party

van Zanten, H. H. E., H. Mollenhorst, C. W. Klootwijk, C. E. v. Middelaar and I. J. M. d. Boer. 2016. Global food supply: Land use efficiency of livestock systems. International Journal of Life Cycle Assessment 21: 747-758, 5, doi: https://doi. org/10.1007/s11367-015-0944-1.
Wilkes, A., and E. Merger. 2014. Scoping of a pasture and livestock sector nationally appropriate mitigation action (NAMA) in the Kyrgyz Republic. Freiburg: Report by UNIQUE Forestry and Land Use for GIZ.

World Bank. 2019. Sustainable Livestock Development Project (P170365) Project Information Document. World Bank.

Zhambakin, Z.A. 1995. Pastures of Kazakhstan [Pastbishcha Kazakhstana]. Almaty: Kainar.

\section{Publisher's Note}

Springer Nature remains neutral with regard to jurisdictional claims in published maps and institutional affiliations.

\section{Submit your manuscript to a SpringerOpen ${ }^{\circ}$ journal and benefit from:}

- Convenient online submission

- Rigorous peer review

- Open access: articles freely available online

- High visibility within the field

- Retaining the copyright to your article

Submit your next manuscript at $\boldsymbol{\nabla}$ springeropen.com 